\title{
Shake Table Response of Unreinforced Masonry and Reinforced Concrete Elements of Special Moment Resisting Frame
}

\author{
Syed Azmat Ali Shah, Junaid Shah Khan (D), Syed Muhammad Ali, Khan Shahzada, \\ Waqar Ahmad, and Junaid Shah \\ Department of Civil Engineering, University of Engineering \& Technology Peshawar, Peshawar, Pakistan \\ Correspondence should be addressed to Junaid Shah Khan; junaidshah@uetpeshawar.edu.pk
}

Received 21 March 2019; Revised 30 April 2019; Accepted 15 May 2019; Published 7 July 2019

Guest Editor: Maria T. de Risi

Copyright ( 92019 Syed Azmat Ali Shah et al. This is an open access article distributed under the Creative Commons Attribution License, which permits unrestricted use, distribution, and reproduction in any medium, provided the original work is properly cited.

\begin{abstract}
Half-scaled reinforced concrete frame of two storeys and two bays with unreinforced masonry (URM) infill walls was subjected to base excitation on a shake table for seismic performance evaluation. Considering the high seismic hazard Zone IV of Pakistan, reinforcement detailing in the RC frame is provided according to special moment resisting frames (SMFRs) requirement of Building Code of Pakistan Seismic-Provisions (BCP SP-2007). The reinforced concrete frame was infilled with in-plane solid masonry walls in its interior frame, in-plane masonry walls with door and window openings in the exterior frame, out-of-plane solid masonry wall, and masonry wall with door and window openings in its interior frame. For seismic capacity qualification test, the structure was subjected to three runs of unidirectional base excitation with increasing intensity. For system identification, ambient-free vibration tests were performed at different stages of experiment. Seismic performance of brick masonry infill walls in reinforced concrete frame structures was evaluated. During the shake table test, performance of URM infill walls was satisfactory until design ground acceleration was $0.40 \mathrm{~g}$ with a global drift of $0.23 \%$. The test was continued till $1.24 \mathrm{~g}$ of base acceleration. This paper presents key findings from the shake table tests, including the qualitative damage observations and quantitative forcedisplacement, and hysteretic response of the test specimen at different levels of excitation. Experimental results of this test will serve as a benchmark for validation of numerical and analytical models.
\end{abstract}

\section{Introduction}

Constructions such as Reinforced Concrete (RC) frame with unreinforced brick masonry (URM) are commonly observed all over the world particularly in the seismically active regions $[1,2]$. In Pakistan, the low-rise URM building is commonly practiced. Due to population growth (207 million, according to 6th Population and Housing Census-2017) and suburbanization, construction trend has been changing from URM buildings to multistory RC frame infilled with URM walls [3]. URM is considered as nonstructural element, and on regular basis it is ignored in the structural analysis and design [4]. However, the presence of the URM wall can significantly alter the lateral load resisting mechanism and complete dynamic behavior by interaction of the infill wall with bounding $\mathrm{RC}$ frame under seismic loading [5]. Frame infill interaction may produce desirable (increase in lateral stiffness, lateral-load capacity, damping, ductility, and energy dissipation capacity) and undesirable effects (soft story mechanism, short column effect, and torsional action) on the global structural performance of the building [6]. Performance of the infilled RC frame has been studied with simplified analytical models (equivalent diagonal strut models by Stafford Smith [7]); Madan et al. [8] detailed finite element analysis (FEA) [9-12] and also with experiments, i.e., quasi-static, pseudodynamic, and shake table tests [13-17]. Many researchers claimed that even though extensive research has been done on masonry infilled RC frames over the decades, the behavior and seismic performance evaluation of such structures is not fully understood [17]. Some design guidelines developed by FEMA 356 [18], ASCE/SEI-7-06 [19], ASCE/SEI Standard 41-06 [20], and ATC-43 [21] for the seismic performance evaluation of masonry infilled RC frame is still considered as unreliable 
and inadequate [22]. The existence of complexities is due to insufficient experimental data on large-scale models of multistory and multibays under dynamic loadings [17].

Different failure modes of masonry infilled structures have been witnessed by the past earthquakes and experimental studies. Severe damage has been demonstrated to these types of structures by previous earthquakes (including 1999 Kocaeli, Turkey earthquake [6]; the 2008 Sichuan, China earthquake; and the 1999 Chi-Chi, Taiwan Earthquake). The damage mechanism comprises of partial or full masonry panel failure, shear failure of columns, plastic hinges at columns ends, soft-storey mechanism, and short column effect [23, 24]. Mehrabi et al. [25] experimentally investigated fourteen half-scale masonry infilled RC frame test specimens and categorized 24 distinct failure modes. Later on Stavridis [22] narrowed down these mechanisms into three main failure modes which includes diagonal cracking (occurs in nonductile frames with strong infill), horizontal shear sliding (occurs in weak frames and weak infill), and corner crushing (occurs in strong frames and strong infill) as shown in Figure 1.

For the reason of damage evaluation of masonry infilled buildings, FEMA 306 [26] characterizes opening within infill as one of the most critical parameters affecting both the global and local seismic behaviors of structure. Doors and windows are the most commonly used types of opening within the infill panels. Opening within the infill panels are perfectly considered as assemblies of subcomponents of the appropriate material which can interact with a surrounding frame and can alter the dynamic behavior of structure. Interaction of strong columns and strong piers of infill panels can cause shear failure in the beams. However, interaction of strong spandrel component with frame can reduce the ductility by inducing short column effects and infill panel causing tensile yielding in the column. Experimental investigations have been made by many researchers [27-30] to study the effect of infill openings.

Limited experimental data are available on the dynamic behavior of RC frame infilled with URM since few shake table studies have been conducted on large scale $[31,32]$. The typical construction of Pakistan is deficient in terms of workmanship, quality of materials, and arrangement of infill regarding the URM infill wall position and size of opening [33]; material properties of local brick masonry such as initial rate of absorption and compressive strength of the mortar are different from those normally used across the world, which results in low compressive and tensile strength and weak bond between bricks and mortar [33, 34]. Experimental assessment of RC frame infilled with URM typically constructed according to local construction practices of Pakistan is unavailable on large scale having multistorey, multibays under real dynamic loading which is necessary for the calibration and verification of analytical model, providing foundation in defining new strategies of design as recommended by ACI (American Concrete Institute). Therefore, a shake table study of three-dimensional, two-storey, two-bay, solid brick masonry infilled frame is conducted on large six degrees of freedom (6 D.O.F) shake table at Earthquake
Engineering Center (EEC), University of Engineering and Technology (UET), Peshawar. The specimen was halfscaled symmetric RC frame model constructed according to special moment-resisting frame (SMRF) requirements of Building Code of Pakistan Seismic-Provisions (BCP SP2007). The RC frame was infilled with URM walls having door and window openings at different locations according to local construction practices of Pakistan. Different arrangements of door and window openings, holdfasts for anchorage of masonry wall to column, and construction with local labors make this structure unique. The test specimen was instrumented with accelerometers and displacement transducers and was subjected to six dynamic tests, including ambient free vibration and sinusoidal base motions of increasing intensity. The specimen was tested until the nonstructural URM walls were severely damaged. Experimental programs, including designing, construction, and testing of the specimen as well as the qualitative and quantitative experimental results are reported in this paper. The main original aspect of this research is to explore the damage mechanism of URM infill and RC frame and its ultimate seismic resistance in terms of maximum base shear force and ultimate drift capacity of SMRFs structures infilled with URM infill walls. The results will be further utilized in developing numerical and analytical models, which will provide foundation for the development of seismic design guidelines of infilled RC frame structures.

\section{Experimental Program}

2.1. Description of Test Specimen. The test specimen selected was RC frame having two storeys and two bays infilled with URM infill walls, which is commonly practiced for low-rise commercial and residential buildings. The test specimen was constructed on the 6 D.O.F shake table at EEC, UET, Peshawar. The three-dimensional, plan and elevation view of the test specimen are shown in Figures 2 and 3, respectively. Extensive experimental investigation through the shake table was carried out to evaluate the performance of brick masonry infilled RC frame structure constructed with indigenous material and labor. The RC frame was designed and constructed according to SMRFs requirement (BCP SP2007). URM walls were constructed by splitting full-scale brick of $9 \times 4.5 \times 3 \mathrm{in}$. $(22.8 \times 11.4 \times 7.6 \mathrm{~cm})$ into half-scale brick of $4.5 \times 2 \times 1.5 \mathrm{in}$. $(11.4 \times 5.0 \times 3.8 \mathrm{~cm})$ discussed in Section 2.2. URM walls of thickness $4.5 \mathrm{in} .(11.4 \mathrm{~cm})$ were constructed with the brickwork of English bond. For bonding of bricks, mortar layer of thickness 1/8 in. $(3.17 \mathrm{~mm})$ and compounding ratio of one cement and five sand was used. The reinforced concrete frame was infilled with in-plane solid masonry walls in its interior frame, inplane masonry walls with door and window openings in exterior frame, out-of-plane solid masonry wall, and masonry wall with door and window openings in its interior frame. To support the dead load of wall above openings, various reinforced concrete lintel beams were provided over the openings. The weight of the test specimen was approximately 16.20 metric tons $(16,200 \mathrm{~kg})$. 


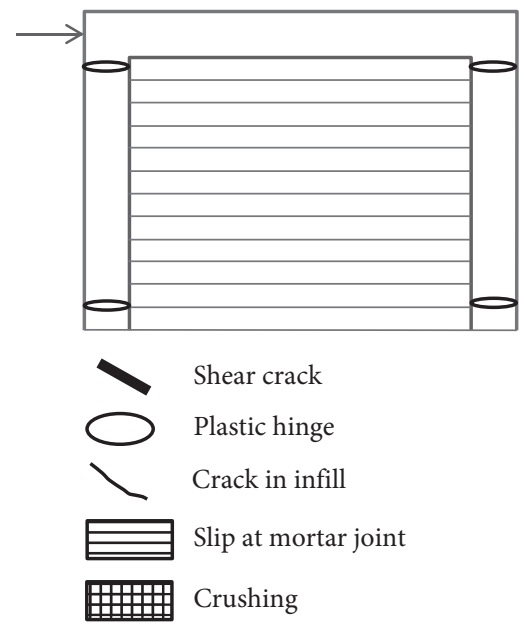

(a)

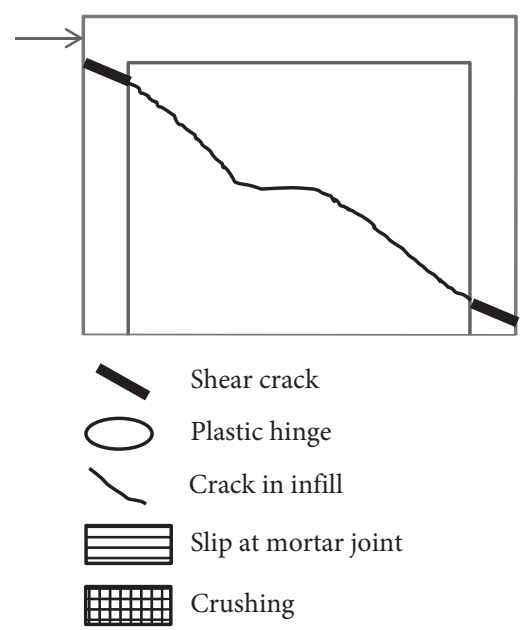

(b)

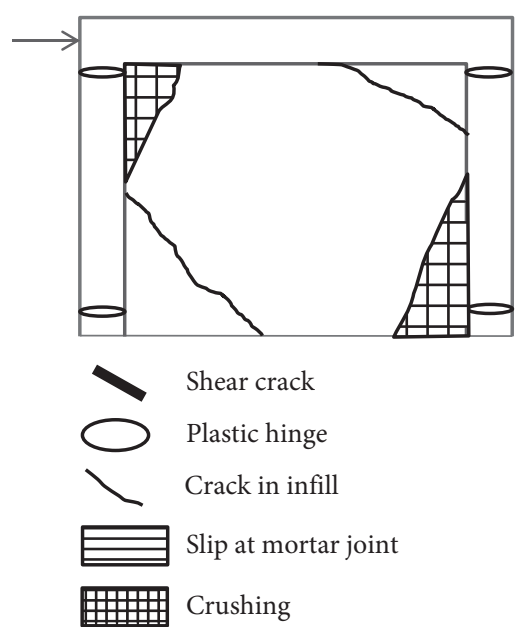

(c)

Figure 1: Three distinct failure mechanisms of masonry infills. (a) Horizontal sliding. (b) Diagonal cracking. (c) Panel or corner crushing.

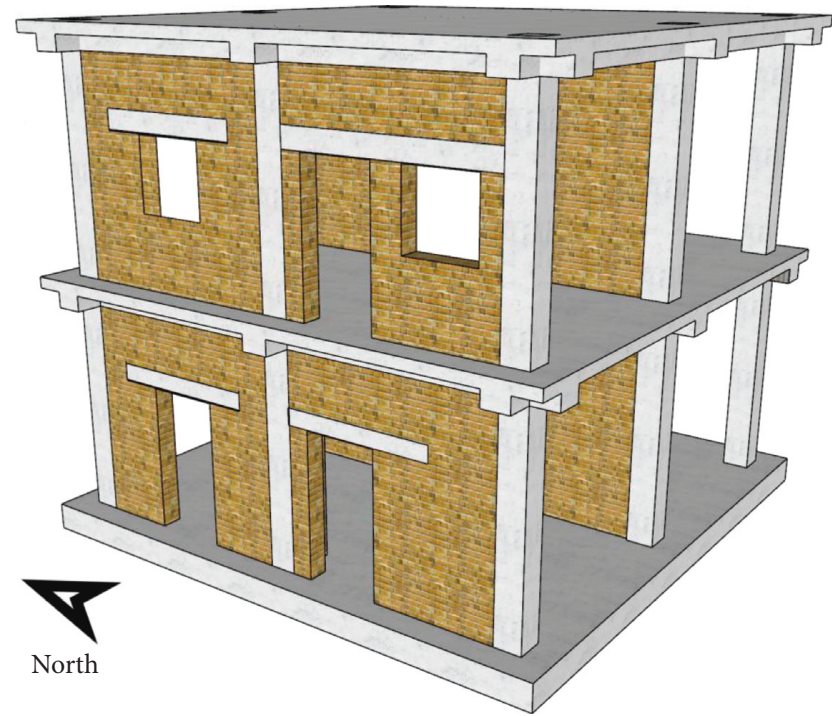

FIGURE 2: Three-dimensional view of prototype.

2.2. Scaling and Designing of RC Frame with URM. Linear geometric dimensions of the structural element beams, columns, and slabs were reduced by a scale factor of 2. Material in the test specimen such as maximum size of aggregates, reinforcement bars, masonry bricks, and vertical and horizontal thickness of mortar layer were also reduced by half scale. Scaling factors for the fundamental quantities are summarized in Table 1 [35].

The construction process includes preparation of the foundation pad which was constructed directly on the shake table anchored with 36 bolts. Followed by the construction of first-storey columns and floor, similarly second-storey columns and floor were constructed. After the construction of RC frame, URM infilled walls were constructed. Reduced live load according to the lateral static force-based method of UBC 97 was used; therefore only $2560 \mathrm{lb}$. (1,200 kg) load were applied on the slab of first story.
The $\mathrm{RC}$ frame was designed with the lateral static forcebased method of seismic design procedures which is based on Uniform Building Code (UBC) 97 and detailed as per SMRF requirements of American Concrete Institute (ACI) Committee 318 Building Code Requirement for Structural Concrete. Beams, columns, and beam-column joints in SMRFs structure is detailed such that it can resist axial, flexural, and shearing actions produced by structure during strong earthquake motion. High seismic hazard region is specified by Zone IV where PGA is greater than $0.32 \mathrm{~g}$ (BCP SP-2007). Seismic hazard of Zone IV with a design PGA of $0.40 \mathrm{~g}$ and soil type B was considered. Loads on structure includes the self-weight for structural beam-column elements and slabs, while superimposed dead load for partition URM infill walls, floor finishing, and live load of $40 \mathrm{psf}$ (Pounds per square foot) $(0.0019 \mathrm{MPa})$ was assigned to the structure. The concrete compressive strength of 3,000 psi (Pounds per square inch) (21 MPa) and reinforcing steel of 50,000 psi (344 MPa) which is typically used was considered in the design. The dimensions of the RC frame and reinforcement bars layout are given in Figure 4. Using 6-inch square of beams and columns, two types of reinforcement were provided at different locations as shown in Figure 5. In section 1-1 of beam, the longitudinal reinforcement of 6 \#3 $(9.52 \mathrm{~mm})$ diameter bars and transverse reinforcement of \#2 $(6.35 \mathrm{~mm})$ diameter bars at 2 inches $(50.8 \mathrm{~mm})$ center-tocenter were provided. Section 2-2 of beam is having longitudinal reinforcement of $5 \# 3(9.52 \mathrm{~mm})$ bars and transverse reinforcement of $\# 2(6.35 \mathrm{~mm})$ bars at 3 inches (76.2 $\mathrm{mm})$ center-to-center.

Longitudinal reinforcement provided in the column section $3-3$ is $8 \# 3(9.52 \mathrm{~mm})$ bars and transverse reinforcement of \#2 $(6.35 \mathrm{~mm})$ bars at 2 inches $(50.8 \mathrm{~mm})$ center-to-center. Column cross section $4-4$ is having 8 \#3 $(9.52 \mathrm{~mm})$ bars of longitudinal reinforcement and \#2 $(6.35 \mathrm{~mm})$ bars at 1.5 inches $(38.1 \mathrm{~mm})$ center-to-center. The transverse reinforcement in the beam and column was provided with $135^{\circ}$ hook. The reinforcements in the slabs of 


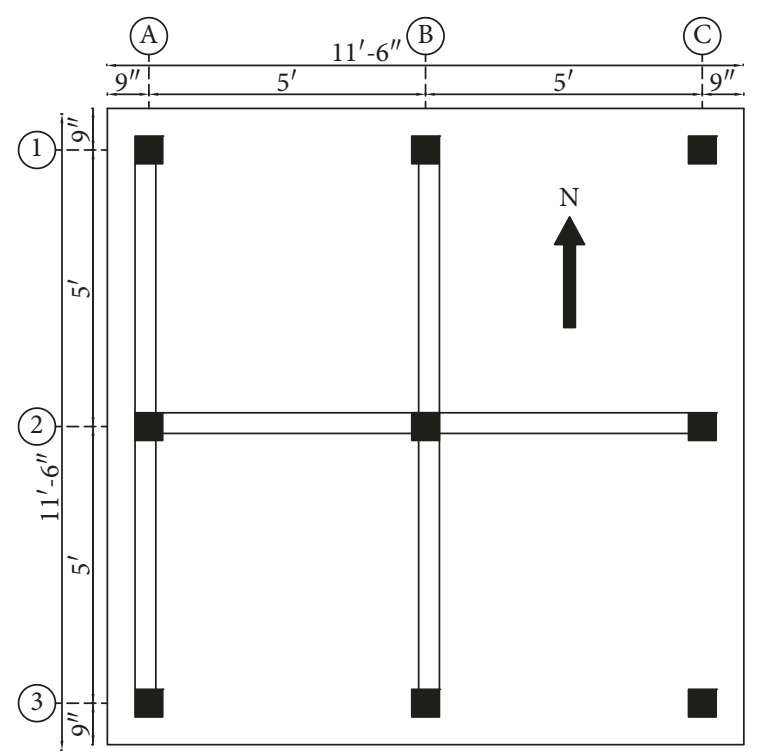

(a)

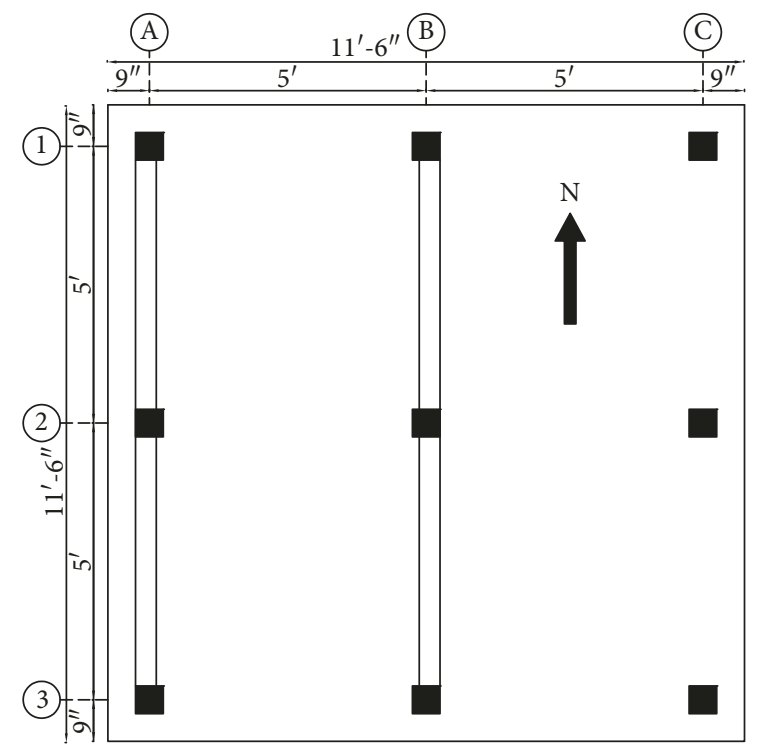

(b)

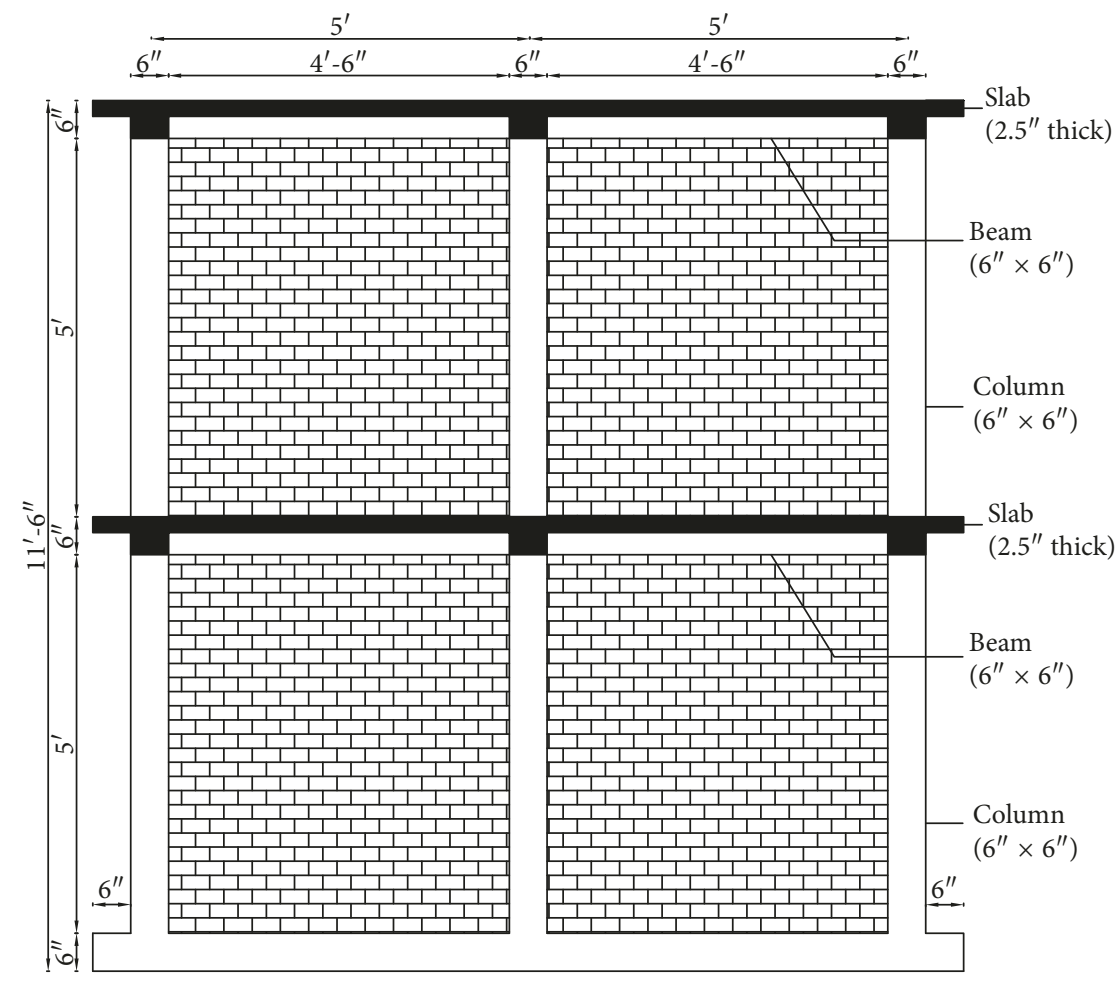

(c)

Figure 3: Plan and elevation view of the test specimen. (a) First-storey wall layout plan. (b) Second-storey wall layout plan. (c) Elevation view of the interior frame.

both the storeys were same, and the steel reinforcement detail of slabs is shown in Figure 6.

2.3. Material Properties. Various tests were conducted to identify the material properties of the test specimen. Tensile strength tests of \#2 $(6.35 \mathrm{~mm})$ and $\# 3(9.52 \mathrm{~mm})$ Grade- 50 reinforcing steel bars were conducted as per ASTM A-615. For compressive strength, tests on concrete cylinders
$6 \times 12$ in. $(15.2 \times 30.4 \mathrm{~cm})$ as per ASTM C873, mortar cubes $2 \times 2$ in. $(5.0 \times 5.0 \mathrm{~cm})$ as per ASTM C109, and masonry prism of $9 \times 8 \times 4.5 \mathrm{in} .(22.8 \times 20.3 \times 11.4 \mathrm{~cm})$ as per ASTM C1314 were carried out as shown in Figure $7($ a). For shear strength, the diagonal masonry prism of $24 \times 24 \times 4.5 \mathrm{in}$. $(60.9 \times 60.9 \times 11.4 \mathrm{~cm})$ as per ASTM E 519 samples was made during the construction of the test specimen as shown in Figure 7(b). Samples of the concrete cylinder were collected at different stages of concrete casting. During construction 
TABLE 1: Scale factors.

\begin{tabular}{lcc}
\hline Item & General case & Scale factor \\
\hline Length, $l$ & $\lambda_{1}=l_{\mathrm{p}} / l_{\mathrm{m}}$ & 2.00 \\
Area, $A$ & $\lambda_{\mathrm{A}}=A_{\mathrm{p}} / A_{\mathrm{m}}=l_{\mathrm{p}}^{2} / l_{\mathrm{m}}^{2}=\lambda_{1}^{2}$ & 4.00 \\
Volume, $V$ & $\lambda_{\mathrm{V}}=V_{\mathrm{p}} / V_{\mathrm{m}}=l_{\mathrm{p}}^{3} / l_{\mathrm{m}}^{3}=\lambda_{1}^{3}$ & 8.00 \\
Moment of inertia, $I$ & $\lambda_{\mathrm{I}}=l_{\mathrm{p}}^{4} / l_{\mathrm{m}}^{4}=\lambda_{1}^{4}$ & 16.00 \\
Linear displacement, $D$ & $\lambda_{\mathrm{D}}=l_{\mathrm{p}} / l_{\mathrm{m}}=\lambda_{\mathrm{l}}$ & 2.00 \\
Angular displacement, $\Theta$ & $\lambda_{\Theta}=1$ & 1.00 \\
Curvature, $k$ & $\lambda_{\mathrm{k}}=1 / \lambda_{1}$ & 0.50 \\
Modulus of elasticity, $E$ & $\lambda_{\mathrm{E}}=E_{\mathrm{p}} / E_{\mathrm{m}}=1$ & 1.00 \\
Stress, $\sigma$ & $\lambda_{\sigma}=\sigma_{\mathrm{p}} / \sigma_{\mathrm{m}}=\lambda_{\mathrm{E}}[\sigma=E]$ & 1.00 \\
Strain, $\varepsilon$ & $\lambda_{\varepsilon}=1$ & 1.00 \\
Mass, Sm & $\lambda_{\mathrm{m}}=\lambda_{\mathrm{Q}} / \lambda_{\mathrm{a}}$ & 4.00 \\
Concentrated load, $Q$ & $\lambda_{\mathrm{Q}}=\lambda_{\mathrm{E}} * \lambda_{1}^{2}$ & 4.00 \\
Shear force, $V$ & $\lambda_{\mathrm{Q}}=\lambda_{\mathrm{E}} * \lambda_{1}^{2}$ & 4.00 \\
Moment, $M$ & $\lambda_{\mathrm{Q}}=\lambda_{\mathrm{E}} * \lambda_{1}^{3}$ & 8.00 \\
Acceleration, $a$ & $\lambda_{\mathrm{a}}=1$ & 1.00 \\
\hline
\end{tabular}

of URM walls, three samples of a masonry prism for compressive strength and three samples of a diagonal prism for tensile strength were constructed and tested after 28 days. Results of material properties are summarized in Table 2.

2.4. Testing Protocols and Input Ground Motions. The structure was subjected to series of sinusoidal base motions with increasing intensity through large 6 D.O.F shake table at EEC, UET, Peshawar. The operating shake table for particular time history requires a self-check test for the development of transfer function, which is dependent on the mass and stiffness of the model. During the validation stage of the shake table with dead weight, development of transfer function with self-check test leads to uncontrollable shaking [36]. Also in the previous studies, problems were encountered by researchers in the form of damage in the model before actual testing [37]. In some of the studies [33, 34, 38], behavior of masonry structures has been extracted through sinusoidal ground motion. Therefore, the structure was subjected to the range of sinusoidal frequencies (0.5$8.00 \mathrm{~Hz}$ ) and time histories as shown in Table 3. The dynamic characteristics of the test specimen such as period and damping were identified using ambient free vibration test before and after shake table test runs in both directions. The destructive and nondestructive test sequences are shown in Table 3.

Sinusoidal input motions were provided at the base of the test specimen in the North-South direction through a signal generator. The amplitude of vibration was kept constant, while the frequency was increased gradually through the signal generator after each 25 seconds. Three types of structural responses: elastic, inelastic, and collapse of nonstructural URM walls, were recorded. The intensity of shaking was increased from test to test; the PGA was increased from 0.05 to $0.15 \mathrm{~g}$ with frequency ranges from $0.50-3.00 \mathrm{~Hz}$ during Test Run-1 given in Figure 8 which was intended to capture response of the structure in elastic range. To cause a moderate level of damage, it was planned to obtain the dynamic response of structure at resonance. Therefore, the base excitation was increased from 0.05 to
$0.60 \mathrm{~g}$ with frequency between 0.50 and $7.50 \mathrm{~Hz}$ at the second stage of experiment shown in Figure 9. In order to observe response of structure at resonance and to cause major collapse in the nonstructural URM walls, the test specimen was subjected to a strong sinusoidal base excitation of PGA 0.05 to $1.24 \mathrm{~g}$ with frequency varying between 0.50 and $8.00 \mathrm{~Hz}$ as shown in Figure 10. It was decided to conclude the base excitation after the collapse of nonstructural URM walls as the masonry walls of the specimen will be strengthened and retrofitted in the future.

2.5. Instrumentation. To measure the displacement and acceleration response histories, the test specimen was instrumented with a total sum of thirteen displacement transducers (DT's) and thirteen uniaxial accelerometers. Prior to the instrumentation, two steel frames were fixed along North and West face of the test specimen. Four accelerometers and four displacement transducers were installed at each floor level and at the base to record the response history in both directions. Instrumentation detail of North and West face is given in Table 4 and Figure 11. All the sensors were calibrated before installation of sensors on steel reference frame and test specimen. The sensors were cross checked to see if all connections are whether functional or not.

The sampling rate was selected to be $200 \mathrm{~Hz}$; to monitor damage in the structure during the shake table test, fifteen video cameras were installed outside and inside the test specimen.

\section{System Identification Tests}

Ambient-free vibration tests were performed at different stages of experiment to determine the natural frequency and damping ratio of the structural system. These tests were conducted to determine dynamic characteristics of structure in both in-plane North-South direction and out-of-plane East-West direction. The test setup for the ambient-free vibration test is shown in Figure 12. A triaxial accelerometer and weak motion seismometer is connected to data acquisition system of a 24-bit recorder (DR-4,000) and facing toward North. The sampling rate was kept $200 \mathrm{~Hz}$, and sample of free vibration-time history recorded after Test Run-3 is given in Figure 13.

3.1. Time Period and Damping. Period of a structure is primarily dependent on the mass and stiffness. Previous studies [39, 40] showed that RC frame without infill has considerably longer period and lower damping ratio compared to RC frame with infill. To have the values of time period and damping of structure, the specimen was suddenly disturbed and the free vibration response was recorded for around 15-30 seconds in both North-South and East-West directions. Period and damping of the structure were estimated from the acceleration-time history and was determined (Chopra, Dynamics of Structures) as follows: 


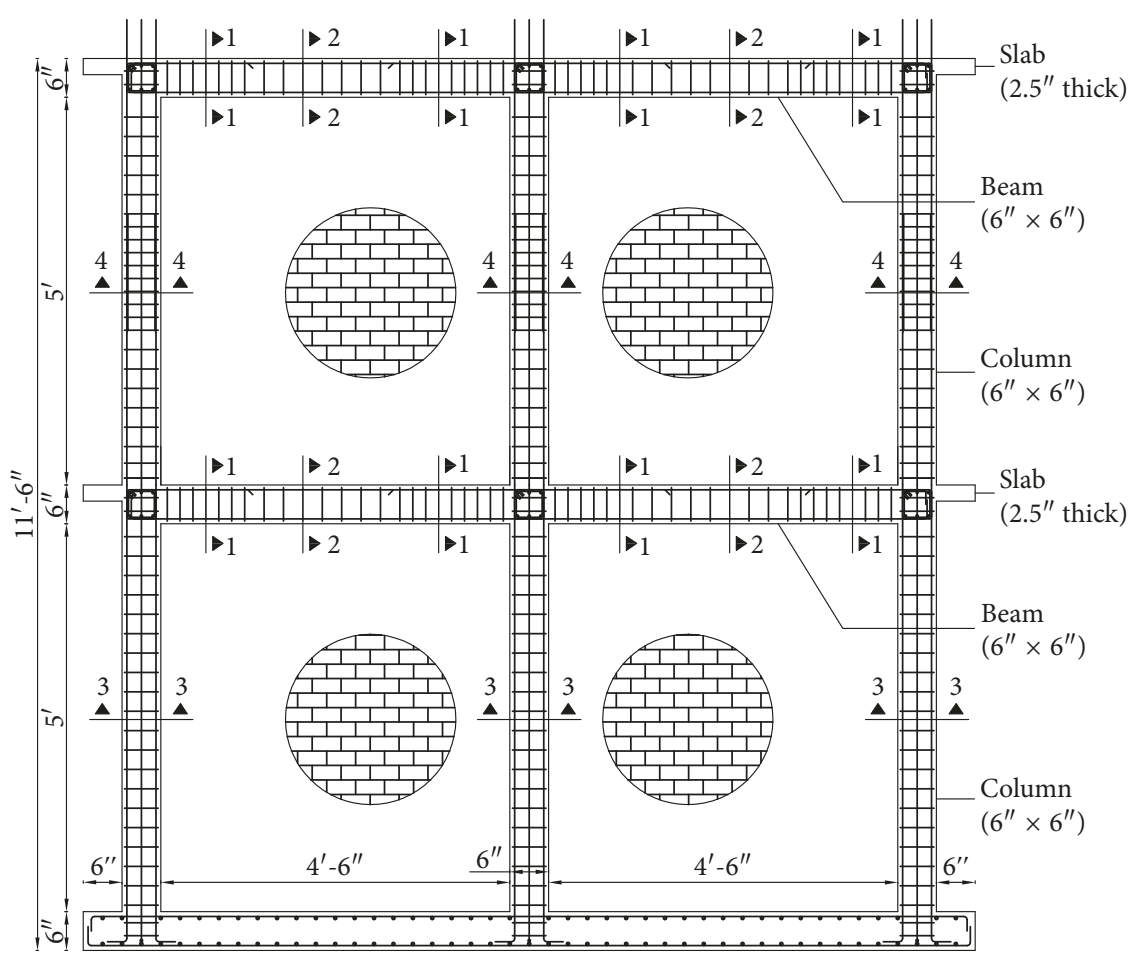

FIgURE 4: Design of the two-storey specimen (dimensions in inches).

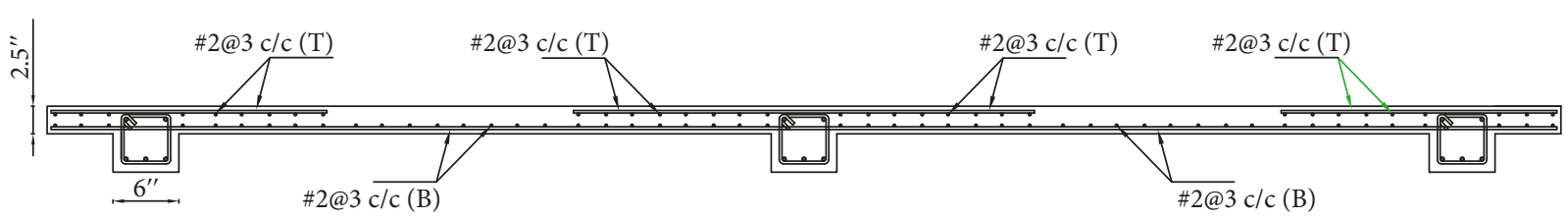

Slab section detail

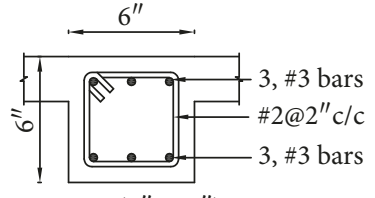

Beam, $\left(6^{\prime \prime} \times 6^{\prime \prime}\right)$

(sec. 1-1)

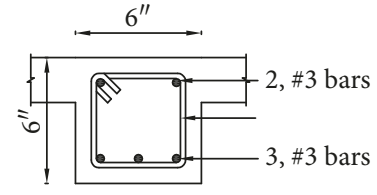

Beam, $\left(6^{\prime \prime} \times 6^{\prime \prime}\right)$

(sec. 2-2)

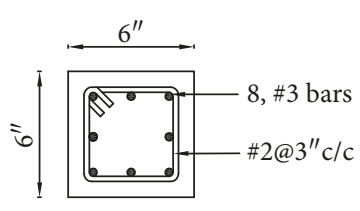

Column, $\left(6^{\prime \prime} \times 6^{\prime \prime}\right)$ (sec. 3-3)

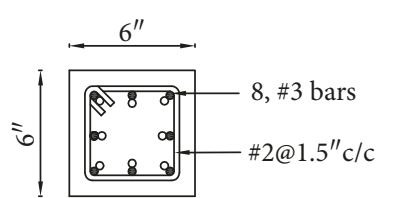

Column, $\left(6^{\prime \prime} \times 6^{\prime \prime}\right)$

(sec. 4-4)

Figure 5: Cross-sectional detail of the RC frame (dimensions in inches).

$$
\zeta=\frac{1}{2 \pi j} \ln \frac{a_{i}}{a_{i+j}},
$$

where $\zeta$ is the damping ratio, $a_{i}$ is the acceleration response at $i^{\text {th }}$ peak, and $a_{i+j}$ is the acceleration response at the latter peak. The test results are summarized in Table 5 and discussed in Section 4.

\section{Results and Discussion}

\subsection{Qualitative Test Results}

4.1.1. Test Run-1. Prior to the Test Run-1, the dynamic characteristics of test specimen such as natural frequency and damping were quantified using the ambient-free vibration test. Natural frequency and damping ratio of $6.45 \mathrm{~Hz}$ and $2.92 \%$ were obtained in the North-South in-plane loading direction of the specimen, while in the East-West out-of-plane loading direction, the natural frequency and damping ratio were found to be $3.48 \mathrm{~Hz}$ and $3.90 \%$, respectively. During the shake table Test Run-1, the specimen was subjected to sinusoidal ground excitation with frequency between 0.50 and $3.12 \mathrm{~Hz}$ and base acceleration between 0.05 and $0.15 \mathrm{~g}$. The frequency of vibration at the base was far away from the fundamental natural frequency $(6.45 \mathrm{~Hz})$ of the specimen. However, no visible damage was induced in the structure. 


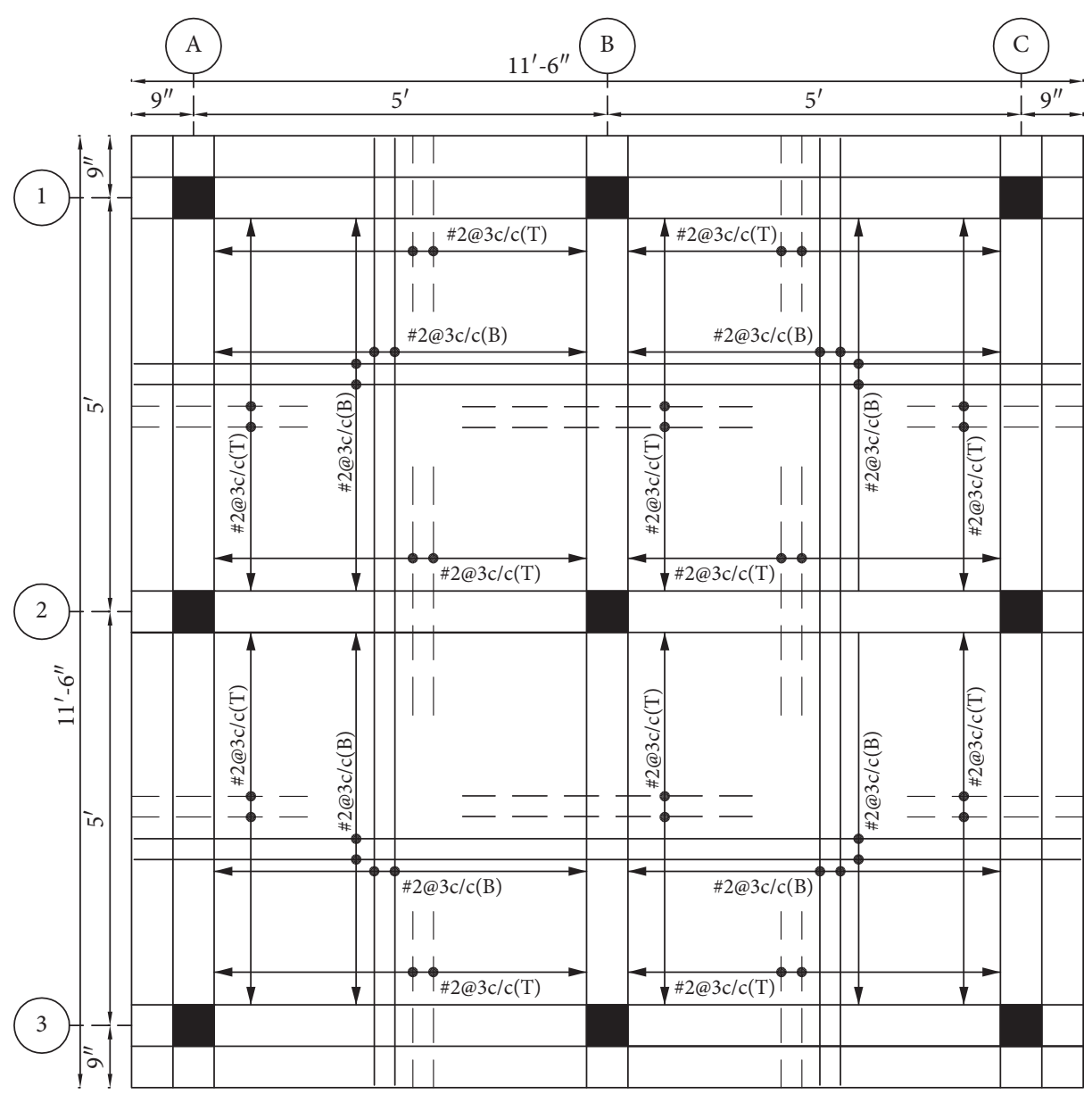

Figure 6: Plan view of first- and second-storey specimens with slab reinforcement details.

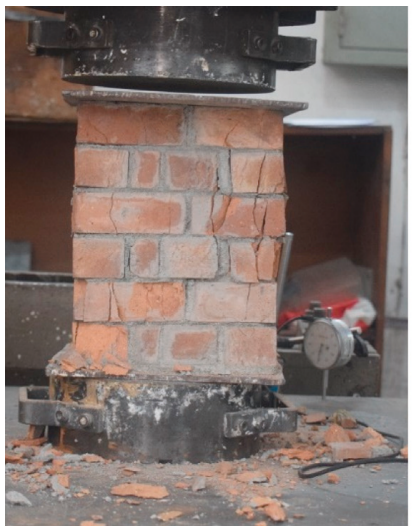

(a)

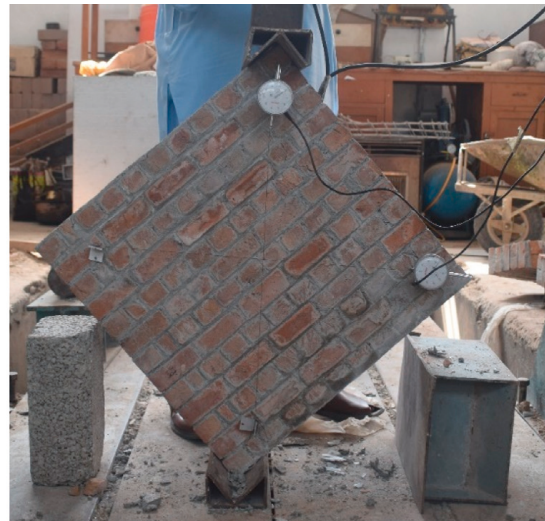

(b)

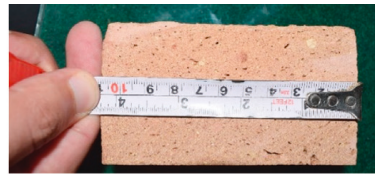

(c)

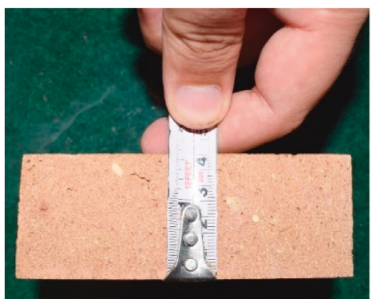

(d)

FIgURE 7: (a) Compressive and (b) diagonal tests of brick prism and (c) length and (d) width of brick specimens.

4.1.2. Test Run-2. Intensity of the base excitation in Test Run-2 was increased with acceleration between 0.05 and $0.60 \mathrm{~g}$. Sinusoidal base motion with frequency $0.50-7.60 \mathrm{~Hz}$ was applied, and the fundamental natural frequency of $6.45 \mathrm{~Hz}$ was estimated before Test Run-1. However, the structure resonated at the frequency of $5.16 \mathrm{~Hz}$. The decrease in the fundamental frequency is due to microcrack initiation during Test Run-1 and Run-2. Moderate level of damage in nonstructural URM infill walls and hairline cracks in RC frame was observed.

The PGA reached $0.42 \mathrm{~g}$ at the resonating frequency $5.16 \mathrm{~Hz}$, which corresponds to design base acceleration of RC frame. Shear cracks originated and extended horizontally along the mortar layers of in-plane URM infill walls towards the bounding RC frame. Vertical shear cracking of mortar layer and separation of URM infill walls from bounding 
TABle 2: Average material properties.

\begin{tabular}{|c|c|c|c|}
\hline Material & & Test type & Test result \\
\hline \multirow{6}{*}{ Concrete } & $\begin{array}{l}\text { Storey } \\
\text { level } 1\end{array}$ & & \\
\hline & Columns & Compressive & $3.741 \mathrm{ksi}(25.79 \mathrm{MPa})$ \\
\hline & $\begin{array}{l}\text { Beams } \\
\text { and slab }\end{array}$ & Compressive & $3.943 \mathrm{ksi}(27.18 \mathrm{MPa})$ \\
\hline & $\begin{array}{l}\text { Storey } \\
\text { level } 2\end{array}$ & & \\
\hline & Columns & Compressive & $4.073 \mathrm{ksi}(28.08 \mathrm{MPa})$ \\
\hline & $\begin{array}{l}\text { Beams } \\
\text { and slab }\end{array}$ & Compressive & $4.193 \mathrm{ksi}(28.90 \mathrm{MPa})$ \\
\hline \multirow{10}{*}{$\begin{array}{l}\text { Reinforcing } \\
\text { steel bar }\end{array}$} & \multirow{10}{*}{$\# 3$} & Tensile & \\
\hline & & Yield stress & $59.42 \mathrm{ksi}(409.68 \mathrm{MPa})$ \\
\hline & & Yield strain & $2.20 \%$ \\
\hline & & Peak stress & $96.34 \mathrm{ksi}(664.24 \mathrm{MPa})$ \\
\hline & & Peak strain & $24.37 \%$ \\
\hline & & Tensile & \\
\hline & & Yield stress & $49.7 \mathrm{ksi}(342.66 \mathrm{MPa})$ \\
\hline & & Yield strain & $1.53 \%$ \\
\hline & & Peak stress & $85.52 \mathrm{ksi}(589.63 \mathrm{MPa})$ \\
\hline & & Peak strain & $21.60 \%$ \\
\hline Brick unit & & Compressive & $5.189 \mathrm{ksi}(35.77 \mathrm{MPa})$ \\
\hline Mortar cubes & & Compressive & $1.348 \mathrm{ksi}(9.29 \mathrm{MPa})$ \\
\hline \multirow{6}{*}{$\begin{array}{l}\text { Masonry } \\
\text { prism }\end{array}$} & \multirow{6}{*}{ Diagonal } & Compressive & $0.742 \mathrm{ksi}(5.119 \mathrm{MPa})$ \\
\hline & & $\begin{array}{l}\text { Young's } \\
\text { modulus }\end{array}$ & $82.56 \mathrm{ksi}(569.23 \mathrm{MPa})$ \\
\hline & & $\begin{array}{l}\text { Strain at } \\
\text { peak stress }\end{array}$ & 0.013 \\
\hline & & $\begin{array}{l}\text { Shear } \\
\text { strength }\end{array}$ & $0.035 \mathrm{ksi}(0.241 \mathrm{MPa})$ \\
\hline & & $\begin{array}{l}\text { Shear } \\
\text { modulus }\end{array}$ & $35.01 \mathrm{ksi}(241.38 \mathrm{MPa})$ \\
\hline & & Shear strain & 0.0004 \\
\hline
\end{tabular}

TABle 3: Actual input motion simulated in different phases of experiment.

\begin{tabular}{|c|c|c|c|}
\hline $\begin{array}{l}\text { Testing } \\
\text { phase }\end{array}$ & Frequencies $(\mathrm{Hz})$ & $\begin{array}{c}\text { Duration of } \\
\text { each } \\
\text { frequency } \\
\text { (sec) }\end{array}$ & $\begin{array}{l}\text { Amplitude } \\
(\mathrm{mm})\end{array}$ \\
\hline $\begin{array}{l}\text { Test } \\
\text { Run-1 }\end{array}$ & $\begin{array}{c}0.50,1.00,1.52,2.08 \\
2.60,3.12\end{array}$ & 25 & 3.00 \\
\hline $\begin{array}{l}\text { Test } \\
\text { Run-2 }\end{array}$ & $\begin{array}{l}0.5,1.00,1.52,2.08,3.12 \\
4.12,5.16,6.25,7.20,7.60\end{array}$ & 25 & 3.00 \\
\hline $\begin{array}{l}\text { Test } \\
\text { Run-3 }\end{array}$ & $\begin{array}{c}0.44,1.04,1.32,1.58,1.82, \\
2.08,2.40,2.65,2.87,3.16 \\
3.43,3.69,4.00,4.16,4.21 \\
4.52,4.72,4.95,5.18,5.45 \\
5.77,6.00,6.22,6.52,6.80 \\
7.00,7.25,7.52,7.80,7.96 \\
4.20,4.27,5.23\end{array}$ & 25 & 4.00 \\
\hline
\end{tabular}

frame were clearly observed. First-storey exterior URM walls (Figure 14(a)) on both north and south side panels went through vertical frame infill separation, and horizontal shear cracking particularly at the interface of beam infill. Excessive damage (relative to the remaining infill panels) occurred in infill panels of exterior second storey (Figure 14(b)), and the top course of the masonry panels collapsed due to

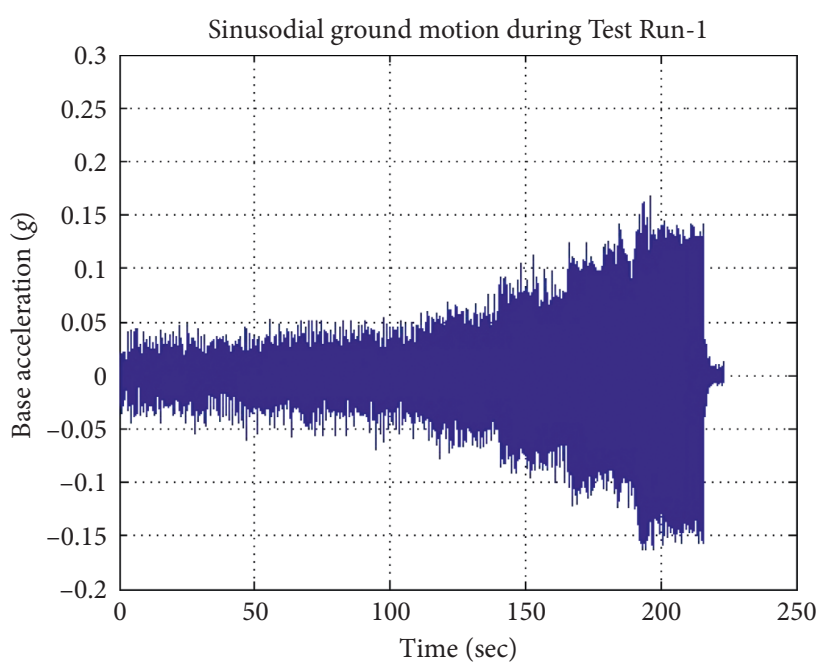

Figure 8: Acceleration recorded at the base during Test Run-1.

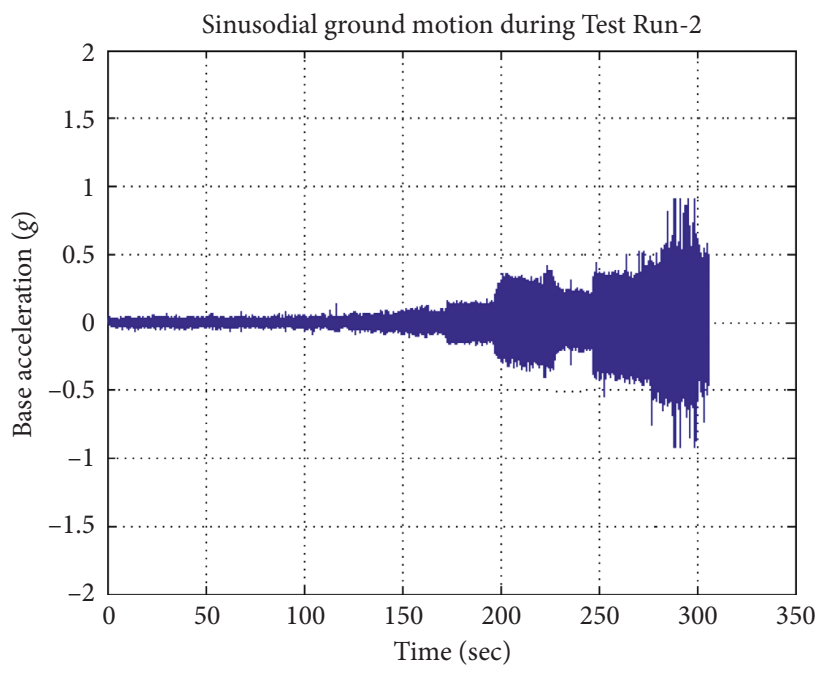

Figure 9: Acceleration recorded at the base during Test Run-2.

inadequate binding of panels with beam, while infill walls of exterior second storey (Figure 14(b)) started separating from the bounding RC frame and a clear horizontal shear crack was observed at the $5^{\text {th }}$ row of infill wall with window opening. Similarly, the frame infill separation at the top interface followed by corner crushing behavior was observed in the interior first-storey (Figure 14(c)) URM walls. At the location of holdfast (mild steel plates for anchorage of masonry wall with adjacent columns), horizontal shear cracks along mortar layer extended throughout the interior masonry panels. Second-storey interior (Figure 14(d)) URM walls received horizontal and vertical separation and cracking and corner crushing. Few bricks in the top course slided outward in the solid out-of-plane (Figure 14(e)) wall.

The frequency of vibration at the base was further increased, and the PGA reached $0.60 \mathrm{~g}$ at the frequency between 6.25 and $7.60 \mathrm{~Hz}$ beyond resonating frequency. The global response (drift and base shear) of the structure reduced with further increase in frequency after resonance. The existing damages in URM walls were further enhanced, 


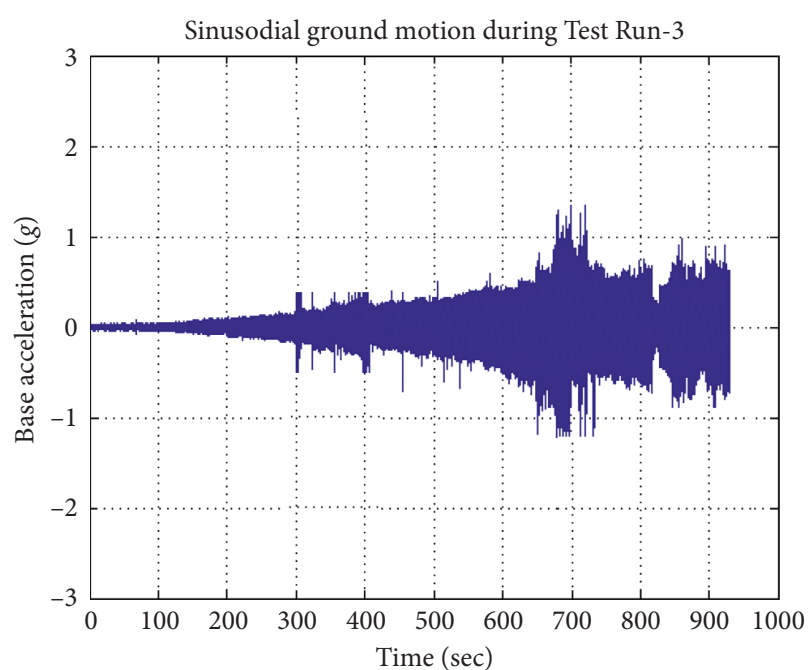

Figure 10: Acceleration recorded at the base during Test Run-3.

TABle 4: Sequence of test.

\begin{tabular}{|c|c|}
\hline Test no. & Test type \\
\hline 1 & Ambient-free vibration system identification test \\
\hline 2 & $\begin{array}{l}\text { Shake table test with sinusoidal base motion } \\
\qquad(0.50-7.50 \mathrm{~Hz})\end{array}$ \\
\hline 3 & $\begin{array}{l}\text { Shake table test with sinusoidal base motion } \\
\qquad(0.50-7.50 \mathrm{~Hz})\end{array}$ \\
\hline 4 & Ambient-free vibration system identification test \\
\hline 5 & $\begin{array}{l}\text { Shake table test with sinusoidal base motion } \\
\qquad(0.50-8.00 \mathrm{~Hz})\end{array}$ \\
\hline 6 & Ambient-free vibration system identification test \\
\hline
\end{tabular}

cracks propagated, and damaged bricks collapsed when the frequency of vibration increased from natural frequency. Due to the low level of vertical stress in unreinforced masonry, URM wall collapsed in shear sliding and flexural (rocking) failure mode. Already cracked portion of URM infill wall with window opening slided outward in shear sliding, and also diagonal tensile cracking was observed in the wall beneath the lintel beam.

The RC frame was investigated with a crack detector after shake table run, determining that $\mathrm{RC}$ frame is only damaged at the column ends and crack width was between $8 \times 10^{-4}$ to $1.5 \times 10^{-3}$ in. $(0.02-0.04 \mathrm{~mm}$.). An ambient-free vibration test was performed after Test Run-2, natural frequency in North-South loading direction decreased to $4.21 \mathrm{~Hz}$, while the damping ratio increased to $5.63 \%$. Natural frequency in the out-of-plane direction decreased from 3.48 to $2.98 \mathrm{~Hz}$, and negligible decrease in the damping ratio from 3.90 to $3.83 \%$ was observed.

4.1.3. Test Run-3. Sinusoidal base excitation with frequency between 0.44 and $7.96 \mathrm{~Hz}$ and ground acceleration ranging from $0.05-1.24 \mathrm{~g}$ was recorded at the base during the final stage of this experiment. The structural peak base shear and lateral drift were recorded at this stage of experiment. Nonstructural URM walls were severely damaged, hairline cracks developed in the second-storey columns, and minor

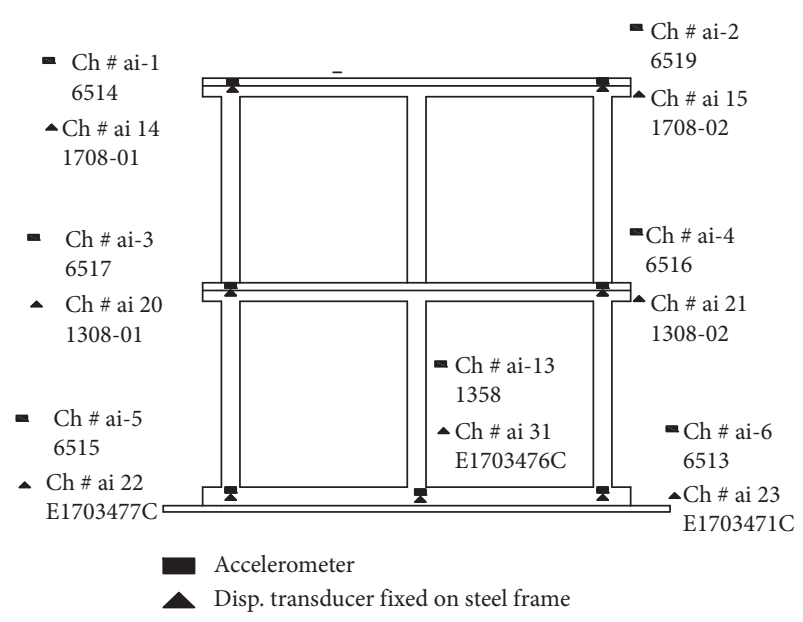

(a)

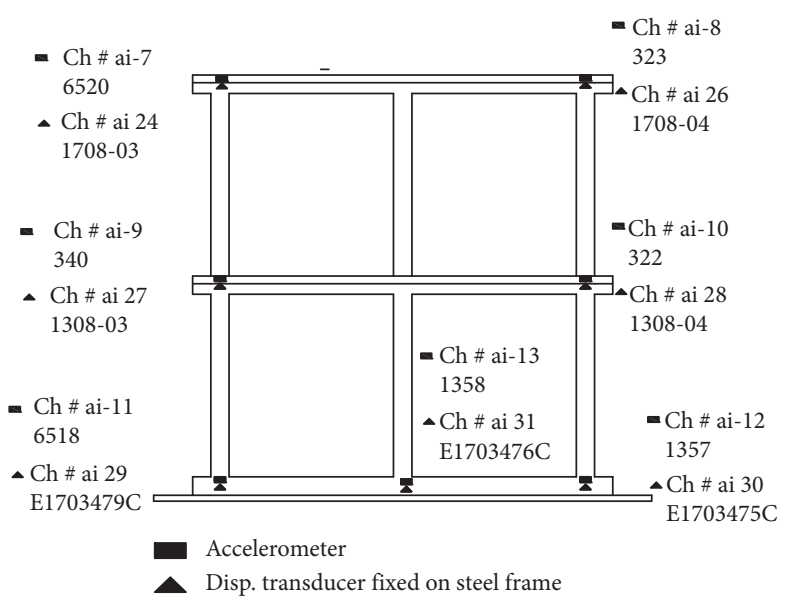

(b)

FIGURE 11: Instrumentation setup. (a) North face instrumentation. (b) West face instrumentation.

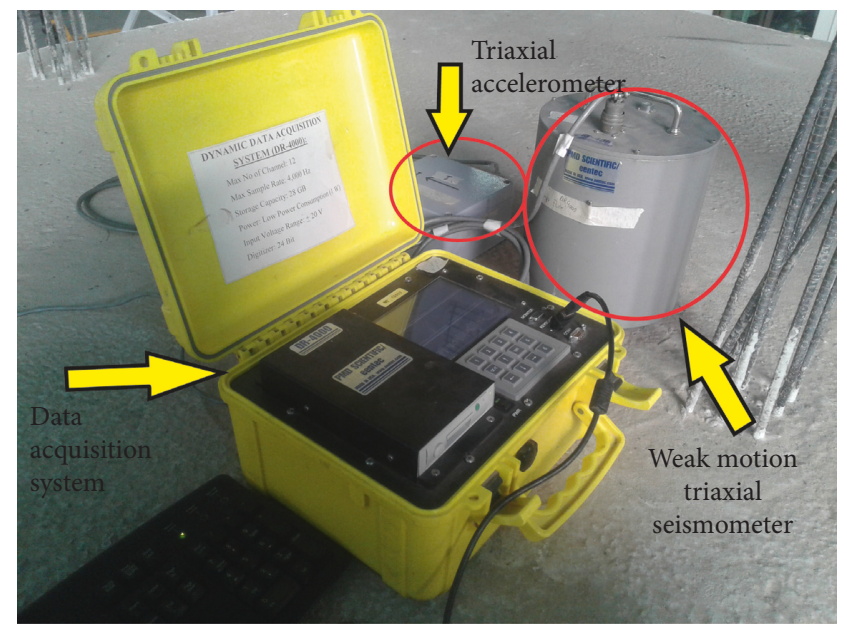

Figure 12: Test setup for the free vibration test.

level of damage occurred in the first-storey columns. During excitation at frequency between 0.44 and $4.00 \mathrm{~Hz}$, the base acceleration was within the range of $0.05-0.40 \mathrm{~g}$. 


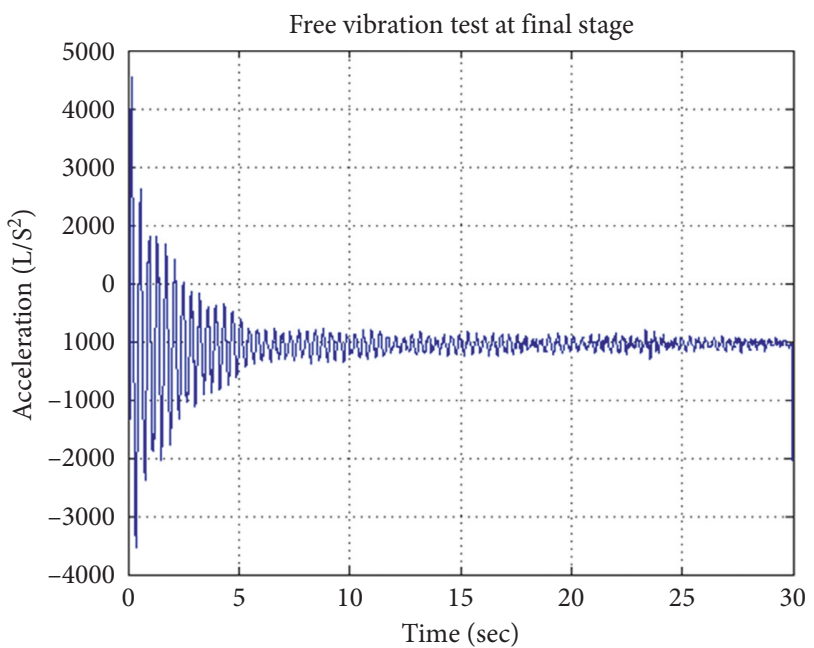

FIGURE 13: Sample of free vibration-time history recorded with the triaxial accelerometer after Test Run-3.

TABLe 5: Detail summary of instrumentation.

\begin{tabular}{|c|c|c|c|c|c|c|}
\hline Channel no & Serial no of sensor & Sensitivity & Type & Range & Location & Remarks \\
\hline \multicolumn{7}{|l|}{ North face } \\
\hline ail & 6514 & $492.2(\mathrm{mv} / \mathrm{g})$ & Accelerometer & $\pm 675 \mathrm{~mm}$ & 2LNA & \\
\hline ai14 & $1708-01$ & $8.5305(\mathrm{mv} / \mathrm{mm})$ & Displacement transducer & & 2LND & \\
\hline ai2 & 6519 & $502(\mathrm{mv} / \mathrm{g})$ & Accelerometer & $\pm 675 \mathrm{~mm}$ & 2RNA & \\
\hline ai15 & $1708-02$ & $8.5332(\mathrm{mv} / \mathrm{mm})$ & Displacement transducer & & 2RND & \\
\hline ai3 & 6517 & $508.9(\mathrm{mv} / \mathrm{g})$ & Accelerometer & $\pm 312 \mathrm{~mm}$ & 1LNA & \\
\hline ai20 & $1308-01$ & $138.2(\mathrm{mv} / \mathrm{mm})$ & Displacement transducer & & 1LND & \\
\hline ai4 & 6516 & $510.1(\mathrm{mv} / \mathrm{g})$ & Accelerometer & $\pm 312 \mathrm{~mm}$ & 1RNA & \\
\hline ai21 & $1308-02$ & $138.1(\mathrm{mv} / \mathrm{mm})$ & Displacement transducer & & 1RND & \\
\hline ai5 & 6515 & $501.1(\mathrm{mv} / \mathrm{g})$ & Accelerometer & $\pm 250 \mathrm{~mm}$ & OLNA & \\
\hline ai22 & E1703477C & $39.81(\mathrm{mv} / \mathrm{mm})$ & Displacement transducer & & OLND & \\
\hline ai6 & 6513 & $499.9(\mathrm{mv} / \mathrm{g})$ & Accelerometer & $\pm 250 \mathrm{~mm}$ & ORNA & \\
\hline ai23 & E1703471C & $39.90(\mathrm{mv} / \mathrm{mm})$ & Displacement transducer & & 0RND & \\
\hline \multicolumn{7}{|l|}{ West face } \\
\hline ai7 & 6520 & $508.5(\mathrm{mv} / \mathrm{g})$ & Accelerometer & $\pm 675 \mathrm{~mm}$ & 2LWA & \\
\hline ai24 & $1708-03$ & $68.632(\mathrm{mv} / \mathrm{mm})$ & Displacement transducer & & 2LWD & \\
\hline ai8 & 323 & 509 (mv/g) & Accelerometer & $\pm 675 \mathrm{~mm}$ & 2RWA & \\
\hline ai26 & $1708-04$ & $68.654(\mathrm{mv} / \mathrm{mm})$ & Displacement transducer & & 2RWD & \\
\hline ai9 & 340 & $510.1(\mathrm{mv} / \mathrm{g})$ & Accelerometer & $\pm 312 \mathrm{~mm}$ & 1LWA & \\
\hline ai27 & $1308-03$ & $137.98(\mathrm{mv} / \mathrm{mm})$ & Displacement transducer & & 1LWD & \\
\hline ai10 & 322 & $496.2(\mathrm{mv} / \mathrm{g})$ & Accelerometer & $\pm 312 \mathrm{~mm}$ & 1RWA & \\
\hline ai28 & $1308-04$ & $170.6(\mathrm{mv} / \mathrm{mm})$ & Displacement transducer & & 1RWD & \\
\hline ai11 & 6518 & 490.1 (mv/g) & Accelerometer & $\pm 250 \mathrm{~mm}$ & 0LWA & \\
\hline ai29 & E1703479C & $39.85(\mathrm{mv} / \mathrm{mm})$ & Displacement transducer & & OLWD & \\
\hline ai12 & 1357 & $5404(\mathrm{mv} / \mathrm{g})$ & Accelerometer & $\pm 250 \mathrm{~mm}$ & 0RWA & Large accelerometer \\
\hline ai30 & E1703475C & $39.75(\mathrm{mv} / \mathrm{mm})$ & Displacement transducer & & ORWD & \\
\hline ai13 & 1358 & $5272(\mathrm{mv} / \mathrm{g})$ & Accelerometer & $\pm 250 \mathrm{~mm}$ & OVCA & Large accelerometer \\
\hline ai31 & E1703476C & $40.01(\mathrm{mv} / \mathrm{mm})$ & Displacement transducer & & 0VCD & \\
\hline
\end{tabular}

Note. 2: second floor, 1: first floor, 0: bottom, L: left side of the frame, R: right side of the frame, N: north face, W: west face, V: vertical direction, C: center, A: accelerometer, D: displacement transducer.

Exterior URM wall of second storey with window opening only, which was already separated from the RC frame up to window height during Test Run-2 (Figure 15(b)), dropped in shear sliding on the table when frequency reached to $3.16 \mathrm{~Hz}$. Also, few rows of interior solid URM walls of both storeys collapsed in shear sliding when frequency was $3.69 \mathrm{~Hz}$.
The PGA reached $1.24 \mathrm{~g}$ at resonating frequency of $4.16 \mathrm{~Hz}$, and bricks in the top few rows of first-storey exterior URM wall with door and window openings collapsed. Also, exterior URM infill wall of second storey with window and door openings separated up to lintel beam height and slided outward horizontally. Out-of-plane URM infill wall of first storey collapsed by initiation of horizontal shear cracks 


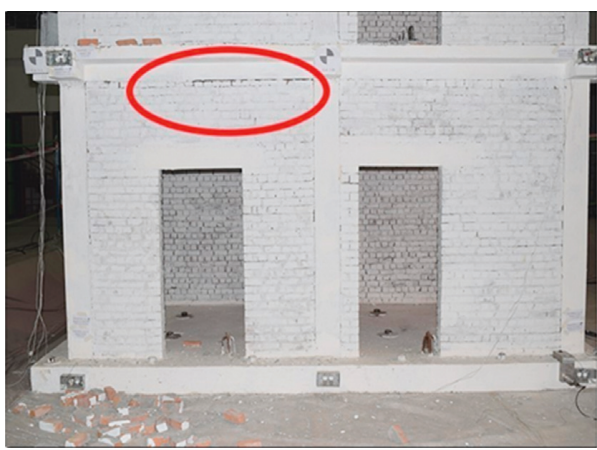

(a)

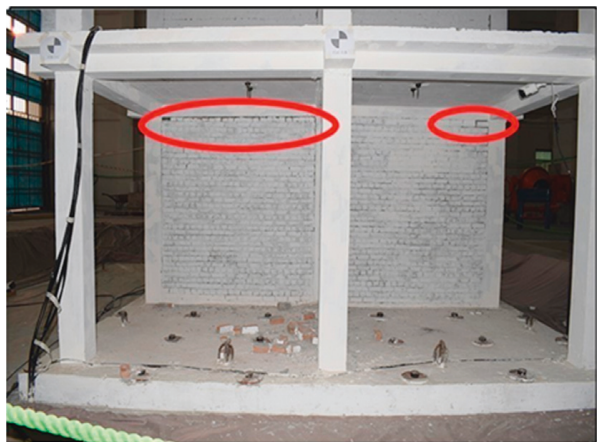

(c)

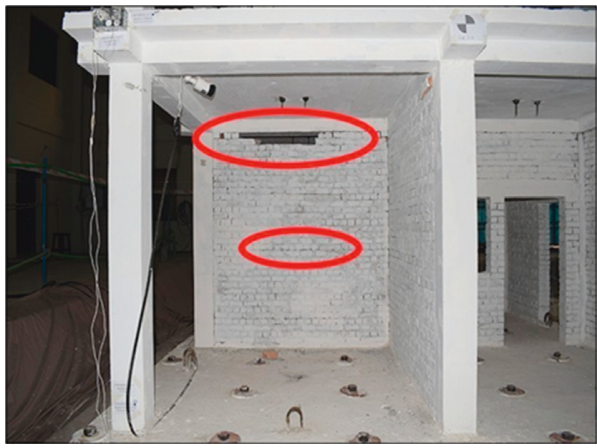

(e)

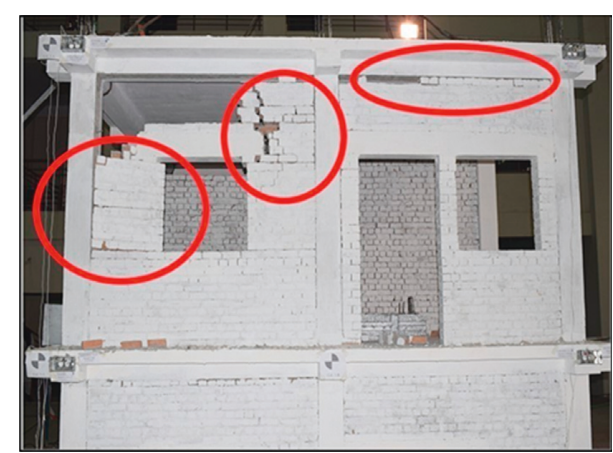

(b)

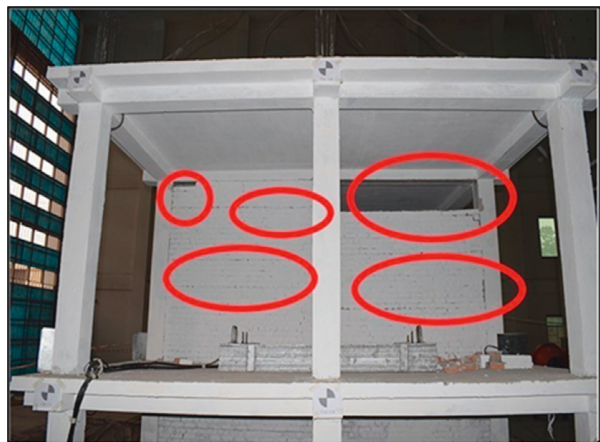

(d)

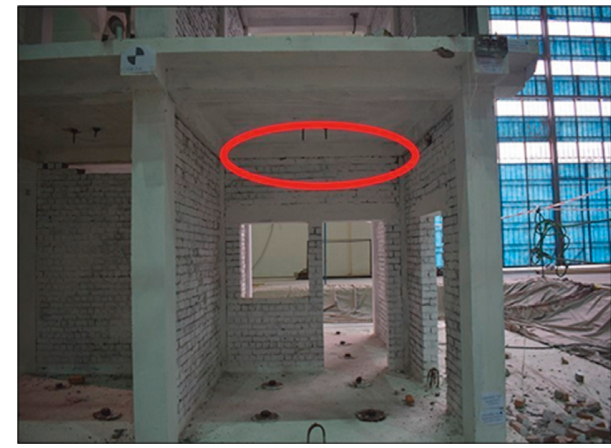

(f)

Figure 14: Damage observations of URM walls after Test Run-2. (a) Exterior infilled frame of first storey. (b) Exterior infilled frame of second storey. (c) Interior infilled frame of first storey. (d) Interior infilled frame of second storey. (e) Out-of-plane solid infilled frame. (f) Out-of-plane with openings infilled frame.

followed by shear sliding and dropping of brick masonry units from upper rows.

Base excitation was increased from $4.21-7.96 \mathrm{~Hz}$, the dynamic response of structure decreased as the frequency of vibration increased above the natural frequency of structure. The vertical and horizontal mortar layers between RC and URM infill walls started crushing and separated more. The test specimen did not experience further visible damage at this phase of the test run.

In order to cause severe damage to the URM infill wall, the structure was excited with a strong sine wave (high amplitude sinusoidal) of frequency between 4.00 and $5.50 \mathrm{~Hz}$ with PGA up to $0.90 \mathrm{~g}$ through a signal generator. The exterior and interior URM infill walls of second storey along south side and exterior infilled walls of first storey collapsed. Diagonal cracking of URM walls was observed beneath the lintel beam of exterior URM walls. Out-of-plane infilled wall up to lintel beam height slided horizontally outwards. The performance of the out-of-plane URM wall with window and door opening was significantly better than the out-of-plane solid masonry wall due to horizontal stiffener provided in the form lintel beam throughout the masonry panel. Damage observations in URM walls after Test Run-3 are shown in Figure 15.

RC frame was visually investigated after Test Run-3, a minor level of damage occurred in the RC frame, and some shear and flexural cracking occurred in the first storey top and bottom of columns. Crack width was investigated with crack detector, and cracks of $2 \times 10^{-3}$ to $1.5 \times 10^{-2} \mathrm{in}$. $(0.05-0.4 \mathrm{~mm})$ was observed at column ends of first storey. On the contrary, the level of damage in second storey was comparatively less than that in first storey, crack width of 


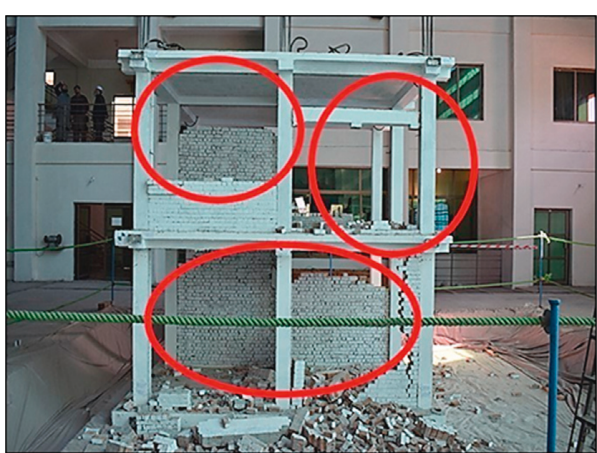

(a)

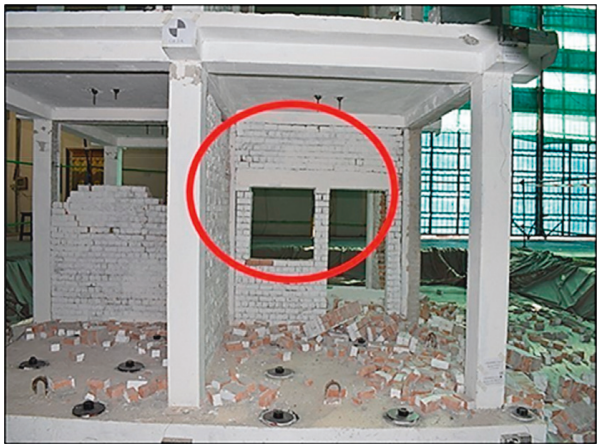

(c)

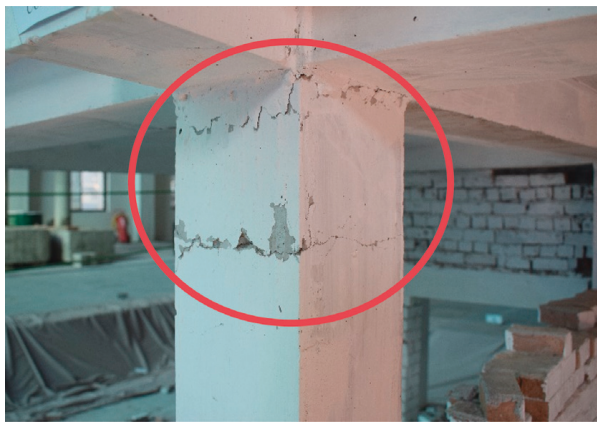

(e)

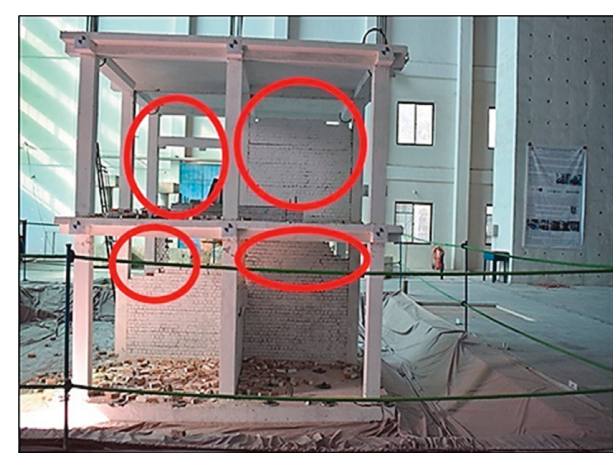

(b)

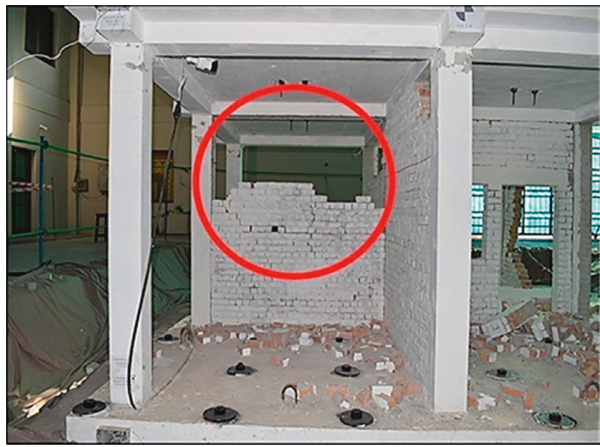

(d)

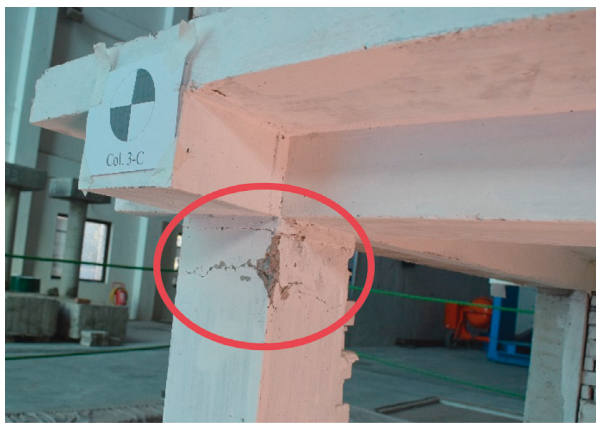

(f)

FigURE 15: Damage observations of URM walls after Test Run-3. (a) West face of the test specimen. (b) East face of the test specimen. (c) South face west-side infilled frame. (d) South face east-side infilled frame. (e) Crack at the top of the exterior column. (f) Crack at the top of the exterior column.

$8 \times 10^{-4}$ to $1.5 \times 10^{-3}$ in. $(0.02-0.04 \mathrm{~mm}$.). The damages observed in RC frame after Test Run-3 is shown in Figure 16. A free vibration test was conducted after Test Run-3, natural frequency in loading direction drops down to $2.67 \mathrm{~Hz}$, and the damping ratio decreases to $4.01 \%$, while in the out-ofplane East-West direction, the natural frequency decreases to $1.93 \mathrm{~Hz}$ and damping ratio to $2.19 \%$. The decrease in natural frequency is the indication of damage in the structure, while loss of URM walls causes drop of damping ratio.

\subsection{Quantitative Test Results}

4.2.1. Force-Displacement. According to Beyer et al. base shear can be calculated by three different methods during shake table test.
Method 1. In this method base shear can be calculated from the force applied by the actuator minus the inertia force of the model foundation and table of the shake table. Inertial force of the model foundation and table can be found through the accelerometer installed on it and from their masses:

$$
V_{b, \text { act }}=F_{\text {act }}-\left[\text { Acc. }\left\{M_{\text {Found }}+M_{\text {Shake table }}\right\}\right],
$$

where $V_{b \text {,act }}=$ base shear calculated from accuator, Acc $=$ acceleration recod of accelerometer, $M_{\text {Found }}=$ mass of the foundation, $M_{\text {Shake table }}=$ mass of the shaketable.

Method 2. In this method, base shear can be calculated by summing the inertial forces of the two stories. Inertial forces can be calculated by acceleration recorded by accelerometers installed on each floor and from mass of the story. 


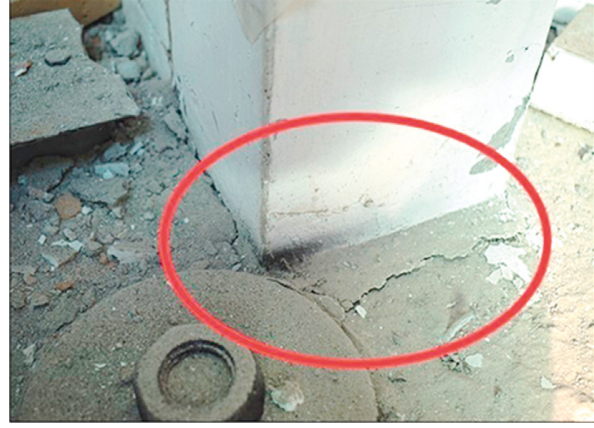

(a)

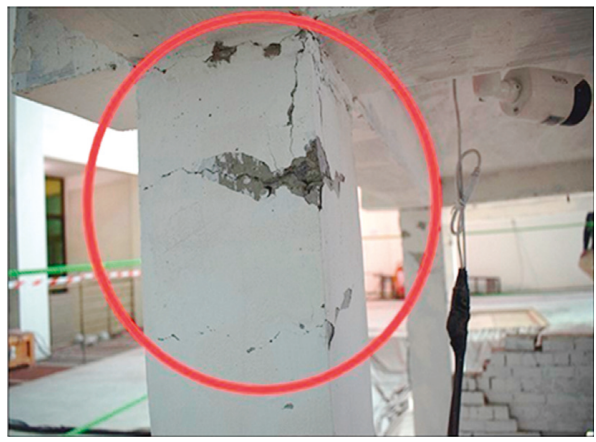

(c)

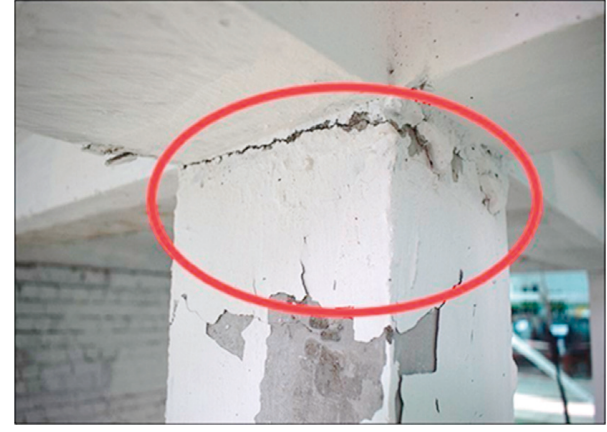

(b)

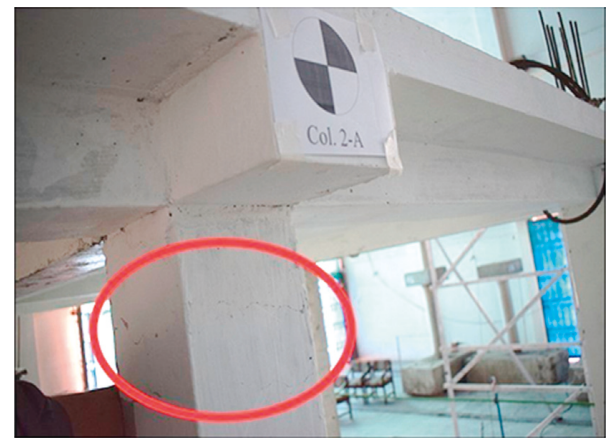

(d)

FIGURE 16: Damage observations of URM walls after Test Run-3. (a) Pulling out of column from foundation. (b) Flexural cracking at top end of first storey. (c) Level of cracking and spalling (1st storey). (d) Level of cracking (2nd storey).

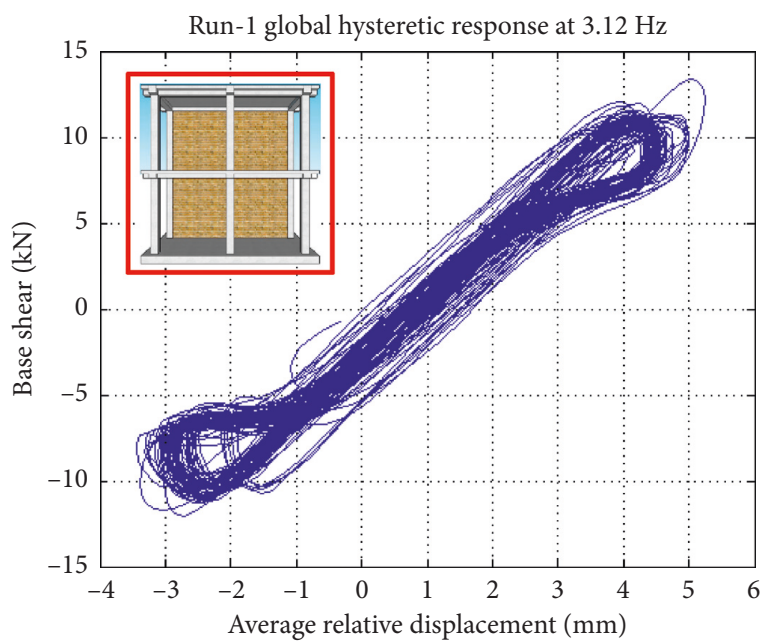

(a)

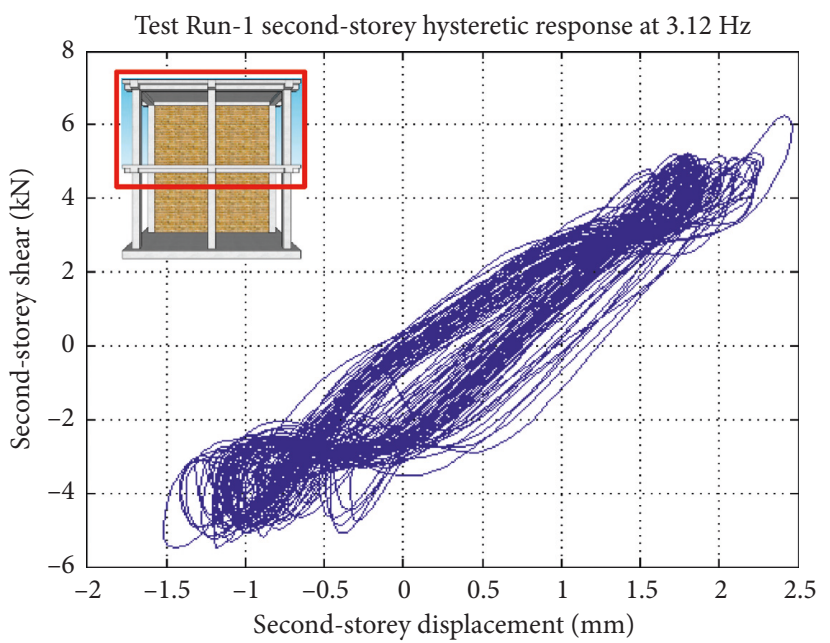

(b)

Figure 17: Continued. 


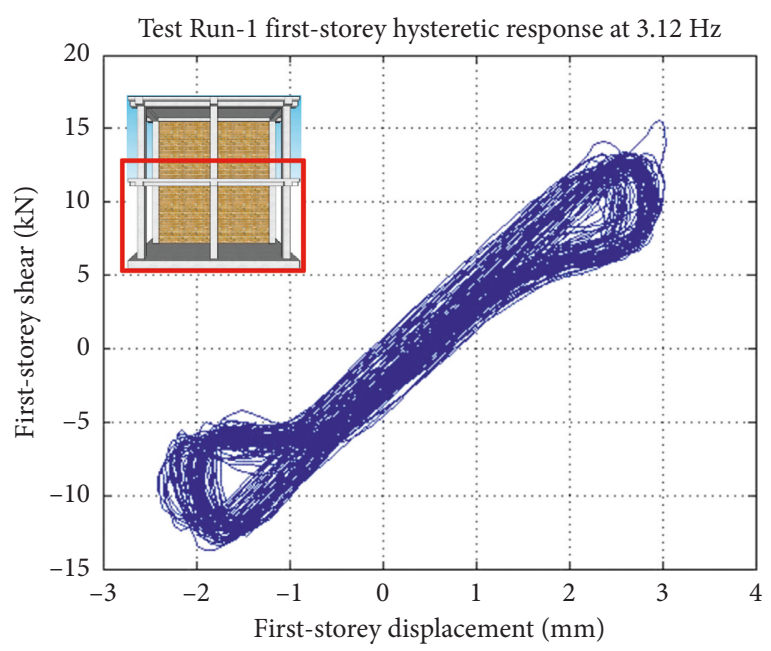

(c)

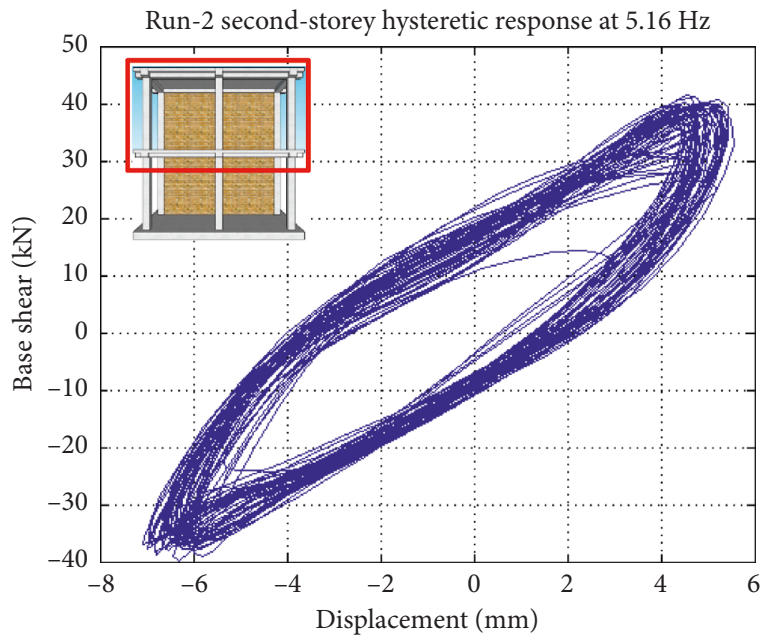

(e)

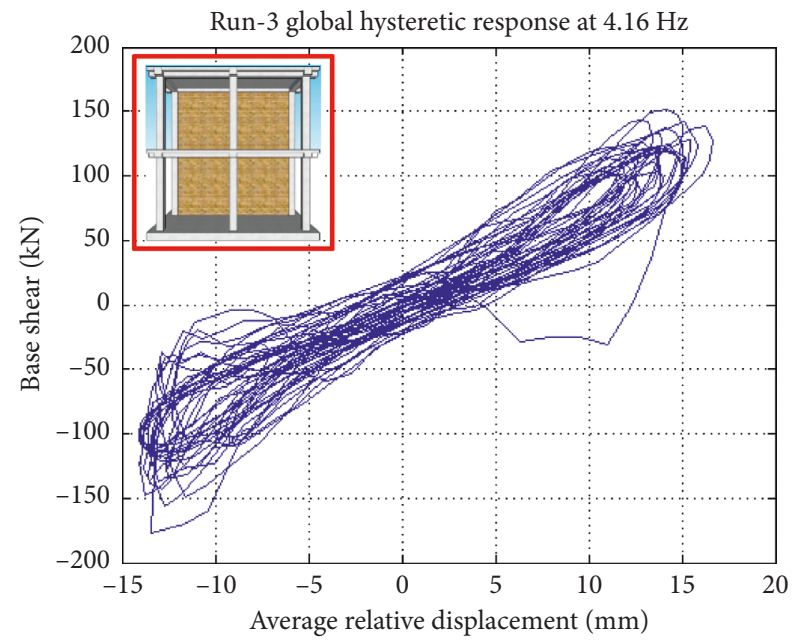

(g)

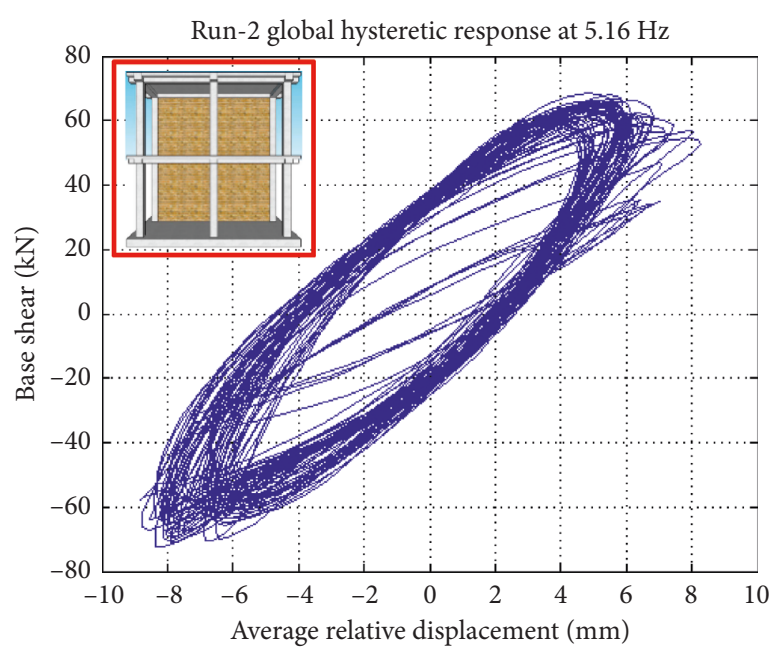

(d)

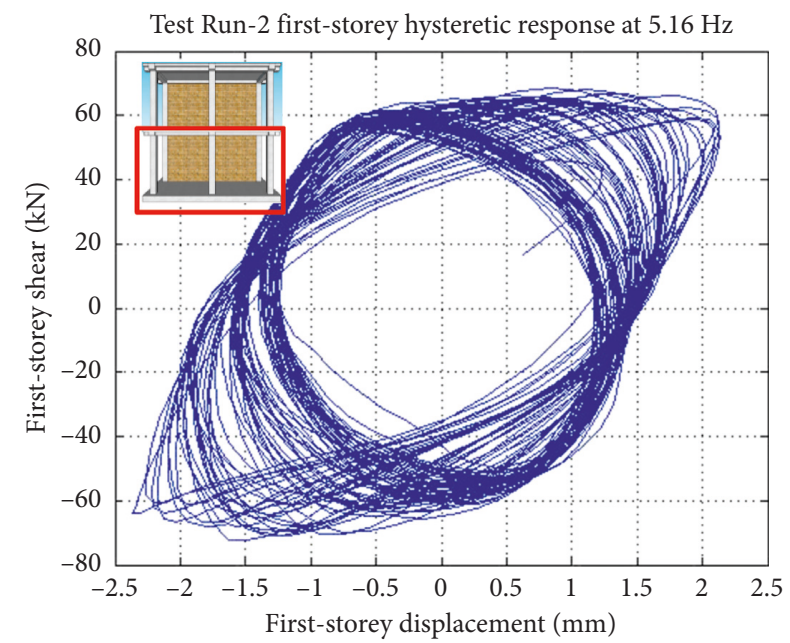

(f)

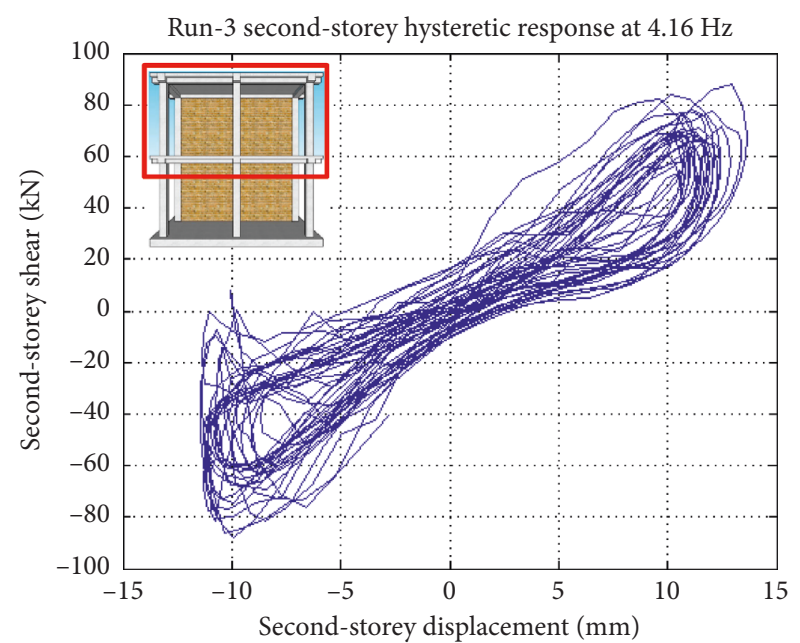

(h)

Figure 17: Continued. 


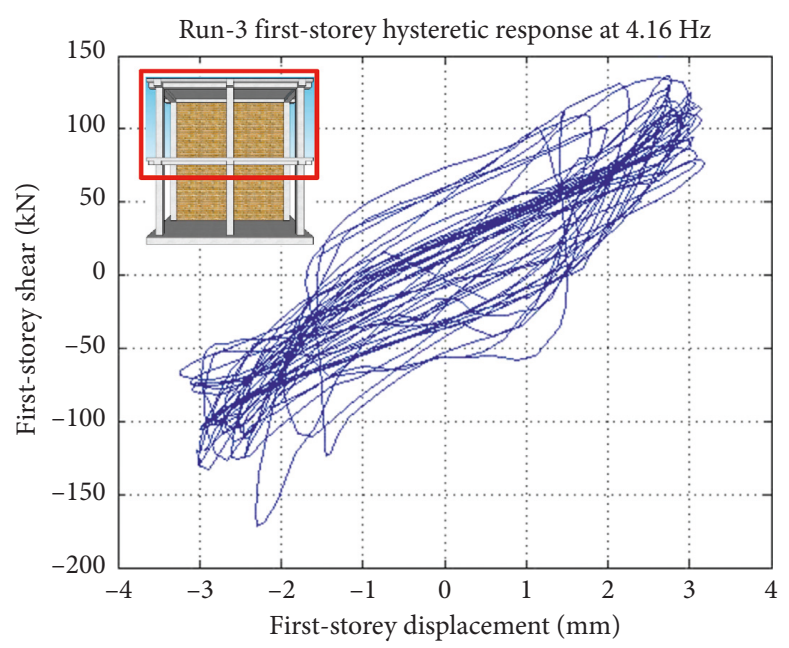

(i)

FiguRe 17: Hysteretic behavior of structure at each test run. (a) Run-1 global hysteretic response at $3.12 \mathrm{~Hz}$. (b) Test Run-1 second-storey hysteretic response at $3.12 \mathrm{~Hz}$. (c) Test Run-1 first-storey hysteretic response at $3.12 \mathrm{~Hz}$. (d) Global hysteretic response at $5.16 \mathrm{~Hz}$. (e) Run-2 second-storey hysteretic response at $5.16 \mathrm{~Hz}$. (f) Test Run-2 first-storey hysteretic response at $5.16 \mathrm{~Hz}$. (g) Run-3 Global hysteretic response at $4.16 \mathrm{~Hz}$. (h) Run-3 second-storey hysteretic response at $4.16 \mathrm{~Hz}$. (i) Test Run-3 first-storey hysteretic response at $4.16 \mathrm{~Hz}$.

TABLe 6: Summary of dynamic identification tests.

\begin{tabular}{|c|c|c|c|c|c|c|}
\hline \multirow{2}{*}{ Testing phase } & \multicolumn{2}{|c|}{ North-South direction } & \multirow{2}{*}{ Damping ratio $\zeta(\%)$} & \multicolumn{2}{|c|}{ East-West direction } & \multirow{2}{*}{ Damping ratio $\zeta(\%)$} \\
\hline & Period (sec) & Frequency $(\mathrm{Hz})$ & & Period (sec) & Frequency $(\mathrm{Hz})$ & \\
\hline Before Test Run-1 & 0.15 & 6.45 & 2.92 & 0.28 & 3.48 & 3.9 \\
\hline After Test Run-2 & 0.23 & 4.21 & 5.63 & 0.33 & 2.98 & 3.83 \\
\hline After Test Run-3 & 0.37 & 2.67 & 4.01 & 0.51 & 1.93 & 2.19 \\
\hline
\end{tabular}

TABLE 7: Summary of structure response.

\begin{tabular}{lcccccc}
\hline \multirow{2}{*}{ Test } & \multirow{2}{*}{$\begin{array}{c}\text { Fundamental time } \\
\text { period before test (s) }\end{array}$} & \multicolumn{2}{c}{$\begin{array}{c}\text { Average } \\
\text { acceleration }\end{array}$} & Global drift (\%) & Global base shear coefficient & \multicolumn{2}{c}{ Damage level } \\
& & Base & Roof & & 0.14 & URM frame \\
\hline Run-1 & 0.16 & 0.13 & 0.18 & 0.17 & 0.66 & None \\
Run-2 & 0.24 & 0.59 & 1.07 & 0.24 & Minor & Mild \\
Run-3 & 0.37 & 1.24 & 2.42 & 0.54 & Minor & Collapse \\
\hline
\end{tabular}

Shake table response of unreinforced masonry and reinforced concrete elements of special moment resisting frame.

$$
V_{b, \text { acc }}=I_{1, \text { acc }}+I_{2, \text { acc }}
$$

Method 3. In this method, base shear can be calculated by the visual measurements of the markers on the slab and foundation.

$$
V_{b, \text { mark }}=I_{1, \text { mark }}+I_{2, \text { mark }} \text {. }
$$

Method 2 was adopted for estimation of base shear in this study. Each storey was instrumented with two accelerometers and two displacement transducers in each direction already discussed in instrumentation Section 2.5, and storey acceleration and displacement was estimated by taking the mean values of acceleration and displacementtime histories, respectively. Inertial storey force was estimated by multiplying average acceleration-time history with approximated storey mass (including self-weight of beams, slabs and half weight of columns below/ above + additional mass). The first-storey shear force is the sum of inertial forces of first and second storeys which is equal to base shear, while the second-storey shear is the inertial force of that storey. Relative displacement of the structure was estimated by subtracting average top displacement from the average base displacement. Interstorey displacement was obtained from the average lateral displacement of floor above relative to the average floor displacement below.

The hysteretic behavior of structure is obtained at global and first and second-storey levels as shown in Figure 17. For global hysteretic behavior, the base shear is plotted with average relative displacement. In order to know whether the distribution of displacement over the RC frame is uniform or concentrated in one of the storey, hysteretic 
curves are plotted for individual storey: first-storey hysteretic curves are obtained by plotting first-storey drift (displacement at first storey top relative to base) with firststorey shear. second-storey shear is plotted with secondstorey drift (roof displacement relative to the top of the first-storey displacement). The hysteretic curve reported here are only for selected frequencies (peak response) of shake table test runs. The peak response takes place at 3.12, 5.16 , and $4.16 \mathrm{~Hz}$ during Test Run-1, Run-2, and Run-3. The test specimen response at different levels of excitation is summarized in Table 6.

\section{Conclusions}

This paper discusses the shake table study conducted on half-scale model of RC frame infilled with URM walls constructed on the multiaxis shake table of EEC, UET, Peshawar. The RC frame was designed for high seismic hazard (Zone IV, with PGA $0.40 \mathrm{~g}$, and soil type B) according to the SMRFs requirement [41]. URM infill walls were constructed with brickwork in English bond with 1 part cement and 5 parts sand. The structure was subjected to ambient-free vibrations and shake table tests. To study the test qualification of SMRFs structure infilled with different arrangement of URM for local and global response to earthquakes, sinusoidal base motion with predominant frequencies of near-field earthquakes has been used to extract behavior. A sequence of three runs of base excitation with increasing intensity was applied. Masonry infills collapsed mainly in shear sliding and pretty much in flexural rocking when PGA reaches $0.42 \mathrm{~g}$, while complete collapse of URM panels takes place when PGA reaches $1.24 \mathrm{~g}$. Weak connections of frame infills particularly at the top layer were the primary cause of damage. URM walls with lintel beam do not provided throughout the masonry panel was much more vulnerable to in-plane and out-of-plane damages. The damping ratio increased after Test Run- 2 and then decreased after Test Run-3 due to loss of in-plane and out-of-plane URM walls. RC frame maintains its stability and does not attract any serious damage even at PGA of $1.24 \mathrm{~g}$. However, the damage mechanism of beam-sway ensured by SMRFs was altered by the column-sway mechanism. Masonry walls within RC frame altered the load path and lateral force distribution (predominant frame action into predominant truss action) among different members of the test structure by amplifying demand force on the adjacent member, causing plastic hinges at columns end. Experimental test results also revealed that the RC frame infilled with different arrangement of URM which is typical of the construction in Pakistan is more vulnerable to seismic actions compared to the other parts of the world. Peak values and damage level at different stages of excitation are summarized in Table 7 .

\section{Data Availability}

Supporting data will be provided.

\section{Conflicts of Interest}

The authors declare that they have no conflicts of interest.

\section{Acknowledgments}

The authors are grateful to the Higher Education Commission, Pakistan, for financially supporting the experimental work presented here and Earthquake Engineering Center, University of Engineering and Technology, for providing testing facilities.

\section{References}

[1] H. Alwashali, Y. Torihata, K. Jin, and M. Maeda, "Experimental observations on the in-plane behaviour of masonry wall infilled RC frames; focusing on deformation limits and backbone curve," Bulletin of Earthquake Engineering, vol. 16, no. 3, pp. 1373-1397, 2018.

[2] O. Bolea, "The seismic behaviour of reinforced concrete frame structures with infill masonry in the Bucharest area," Energy Procedia, vol. 85, pp. 60-76, 2016.

[3] Y. I. Badrashi, Response modification factors, Ph.D. thesis, Department of Civil Engineering, University of Engineering \& Technology Peshawar, Peshawar, Pakistan, 2006.

[4] H. Al-Washali, Y. Suzuki, and M. Maeda, "Seismic evaluation of reinforced concrete buildings with masonry infill wall," in Proceedings of the 16th World Conference of Earthquake Engineering, Chile, At Santiago, Chile, January 2017.

[5] H. B. Kaushik, D. C. Rai, and S. K. Jain, "Code approaches to seismic design of masonry-infilled reinforced concrete frames: a state-of-the-art review," Earthquake Spectra, vol. 22, no. 4, pp. 961-983, 2006.

[6] EERI 2000, 1999 Kocaeli, Turkey, Earthquake Reconnaissance Report, vol. 16, EERI, Oakland, CA, USA, 2000.

[7] B. S. Smith, "Lateral stiffness of infilled frames," Journal of Structural Division, ASCE, vol. 88, no. 6, pp. 183-199, 1962.

[8] A. Madan, A. M. Reinhorn, J. B. Mander, and R. Valles, "Modeling of masonry infill panels for structural analysis," Journal of Structural Engineering, vol. 123, no. 10, pp. 12951302, 1997.

[9] G. Al-Chaar, "Evaluating strength and stiffness of unreinforced masonry infill structures," ERDC/CERL TR-02-01, U.S. Army Corps of Engineers, Construction Engineering Research Laboratories, Washington, DC, USA, 2002.

[10] G. Al-Chaar, A. B. Mehrabi, and T. Manzouri, "Finite element interface modeling and experimental verification of masonryinfilled R/C frames," Masonry Society Journal, vol. 26, no. $1-47,2008$.

[11] H. R. Lotfi and P. B. Shing, "An appraisal of smeared crack models for masonry shear wall analysis," Computers \& Structures, vol. 41, no. 3, pp. 413-425, 1991.

[12] T. Manzuri, "Nonlinear finite element analysis and experimental evaluation of retrofitting techniques for unreinforced masonry structures," Dissertation, University of Colorado at Boulder, Boulder, CO, USA, 1995.

[13] K. Beyer, M. Tondelli, S. Petry, and S. Peloso, "Dynamic testing of a four-storey building with reinforced concrete and unreinforced masonry walls: prediction, test results and data set," Bulletin of Earthquake Engineering, vol. 13, no. 10, pp. 3015-3064, 2015.

[14] M. N. Fardis, S. N. Bousias, G. Franchioni, and T. B. Panagiotakos, "Seismic response and design of RC structures with plan-eccentric masonry infills," Earthquake 
Engineering \& Structural Dynamics, vol. 28, no. 2, pp. 171-191, 1999.

[15] A. Hashemi and K. M. Mosalam, "Seismic evaluation of reinforced concrete buildings including effects of masonry infill walls," PEER Report 2007/100, University of California, Berkeley, CA, USA, 2007.

[16] J. Leite and P. B. Lourenço, "Solutions for infilled masonry buildings: shaking table tests," in Proceedings of the 15th International Brick and Block Masonry Conference, Florianópolis, Brazil, June 2012.

[17] A. Stavridis, I. Koutromanos, and P. B. Shing, "Shake-table tests of a three-story reinforced concrete frame with masonry infill walls," Earthquake Engineering \& Structural Dynamics, vol. 41, no. 6, pp. 1089-1108, 2012.

[18] FEMA 356, Global Topics Report on the Pre-Standard and Commentary for the Seismic Rehabilitation of Buildings, American Society of Civil Engineers, Reston, Virginia for Federal Emergency Management Agency, Washington, DC, USA, 2000.

[19] ASCE/SEI-7-06, Minimum Design Loads for Buildings and Other Structures, American Society of Civil Engineers, Reston, VA, USA, 2006.

[20] ASCE/SEI Standard 41-06, Seismic Rehabilitation of Existing Buildings, American Society of Civil Engineers, Reston, VA, USA, 2006.

[21] ATC-43, FEMA 306: Evaluation of Earthquake Damaged Concrete and Masonry Wall Buildings, Federal Emergency Management Agency, Washington, DC, USA, 1998.

[22] A. Stavridis, Analytical and experimental study of seismic performance of reinforced concrete frames infilled with masonry walls, Ph.D. dissertation, University of California, San Diego, CA, USA, 2009.

[23] V. Li, "Engineered cementitious composite (ECC): material, structural, and durability performance," in Concrete Construction Engineering Handbook, E. Nawy, Ed., pp. 24-46, CRC Press, Boca Raton, FL ,USA, Second edition, 2008.

[24] H. Sezen, A. S. Whittaker, K. J. Elwood, and K. M. Mosalam, "Performance of reinforced concrete buildings during the August 17, 1999 Kocaeli, Turkey earthquake, and seismic design and construction practise in Turkey," Engineering Structures, vol. 25, no. 1, pp. 103-114, 2003.

[25] A. B. Mehrabi, P. B. Shing, M. P. Schuller, and J. L. Noland, "Performance of masonry-infilled R/C frames under in-plane lateral loads," Report CU/SR-94/6, Department of Civil, Environmental \& Architectural Engineering, University of Colorado Boulder, Boulder, CO, USA, 1994.

[26] FEMA-306, "Evaluation of earthquake damaged concrete and masonry wall buildings basic procedures manual," FEMA-306, pp. 183-213, Applied Technology Council, Redwood City, CA, USA, 1999.

[27] J. R. Benjamin and H. A. Williams, "The behavior of one-story shear walls," Proceedings of ASCE, vol. 4, no. 1723, pp. 1-30, 1958.

[28] D. Mallick and R. Garg, "Effect of openings on the lateral stiffness of infilled frames," Proceedings of the Institution of Civil Engineers, vol. 49, no. 2, pp. 193-209, 1971.

[29] T. C. Liauw, "Tests on multistorey infilled frames subjected to dynamic lateral loading," ACI Journal Proceedings, vol. 76, no. 4, pp. 551-564, 1979.

[30] J. L. Dawe and T. C. Young, "An investigation of factors influencing the behavior of masonry infill in steel frames subjected to in-plane shear," in Proceedings of the 7th International Brick Masonry Conference, Melbourne, Australia, February 1985.
[31] A. Hashemi and K. M. Mosalam, "Shake-table experiment on reinforced concrete structure containing masonry infill wall," Earthquake Engineering \& Structural Dynamics, vol. 35, no. 14, pp. 1827-1852, 2006.

[32] P. B. Shing and I. Koutromanos, "Seismic performance of masonry infilled RC frames with and without retrofit," Journal of Earthquake and Tsunami, vol. 7, no. 3, article 1350023, 2013.

[33] K. Shahzada, A. Naeem Khan, A. S. Elnashai, A. Naseer, M. Javed, and M. Ashraf, "Shake table test of confined brick masonry building," Advanced Materials Research, vol. 255260, pp. 689-693, 2011.

[34] M. Ashraf, Development of cost-effective and efficient retrofitting technique for masonry buildings in Pakistan, Ph.D. thesis, Department of Civil Engineering, University of Engineering \& Technology, Peshawar, Pakistan, 2010.

[35] H. G. Harris and G. M. Sabnis, Structural Modeling and Experimental Techniques, CRC Press, Boca Raton, FL, USA, 1999.

[36] J. Shah, "Validation of 6 DOF shake table for testing of half scaled reinforced concrete model," International Journal of Advance Engineering and Research Development, vol. 5, no. 10, pp. 106-111, 2018.

[37] M. Rizwan, N. Ahmad, and A. N. Khan, "Seismic performance of SMRF compliant and non-compliant RC frames," $A C I$ Structural Journal, 2017.

[38] R. Zarnic, S. Gosti, A. J. Crewe, and C. A. Taylor, "Shaking table tests of 1: 4 reduced-scale models of masonry infilled reinforced concrete frame buildings," Earthquake Engineering and Structural Dynamics, vol. 30, no. 6, pp. 819-834, 2001.

[39] V. Bertero and S. Brokken, "Infills in seismic resistant building," Journal of Structural Engineering, vol. 109, no. 6, pp. 1337-1361, 1983.

[40] K. M. Amanat and E. Hoque, "A rationale for determining the natural period of RC building frames having infill," Engineering Structures, vol. 28, no. 4, pp. 495-502, 2006.

[41] BCP-SP, Building Code of Pakistan Seismic Provisions, Islamabad: Ministry of Housing, Government of Pakistan, Islamabad, Pakistan, 2007. 


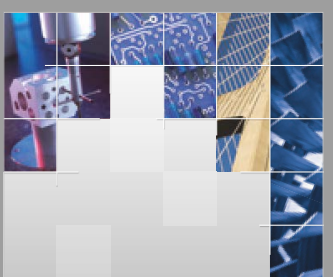

\section{Enfincering}
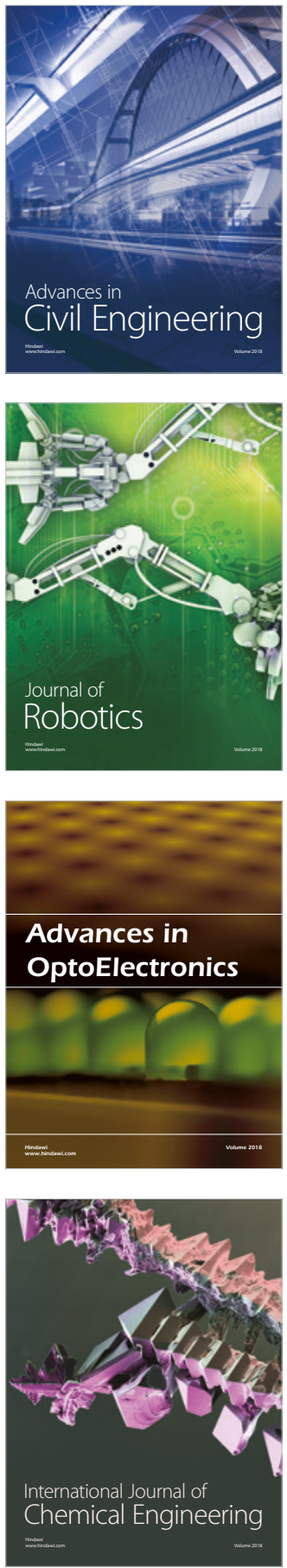

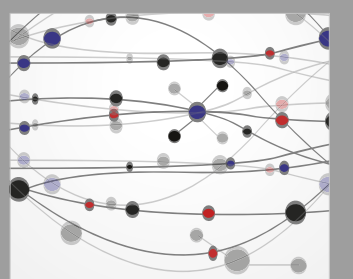

\section{Rotating \\ Machinery}

The Scientific World Journal

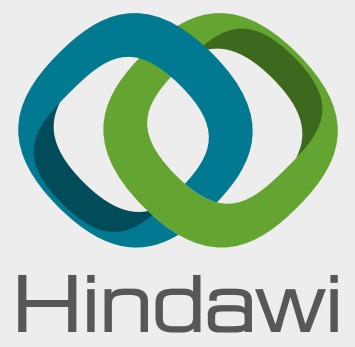

Submit your manuscripts at

www.hindawi.com
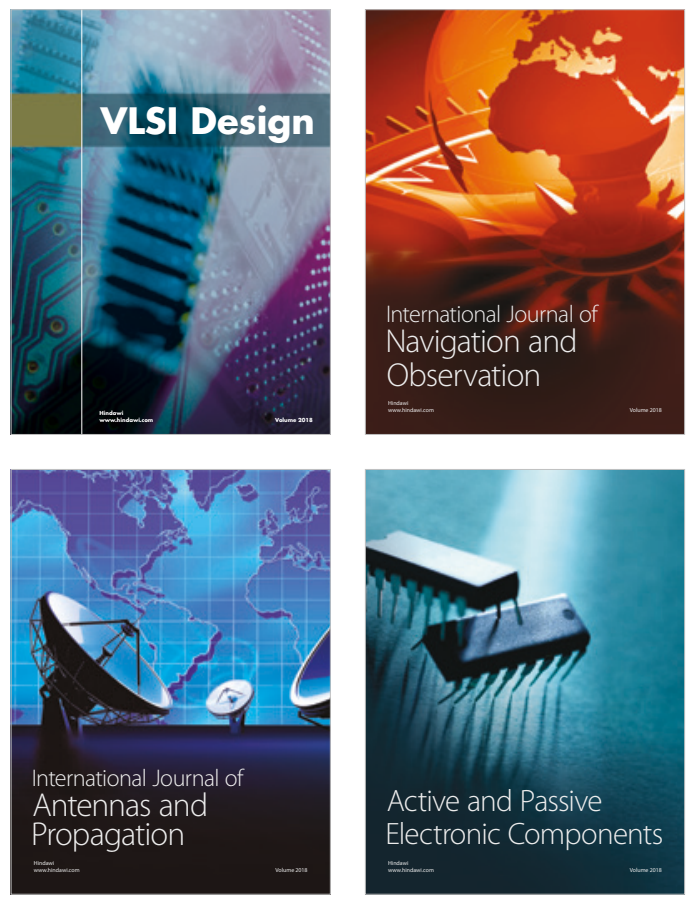
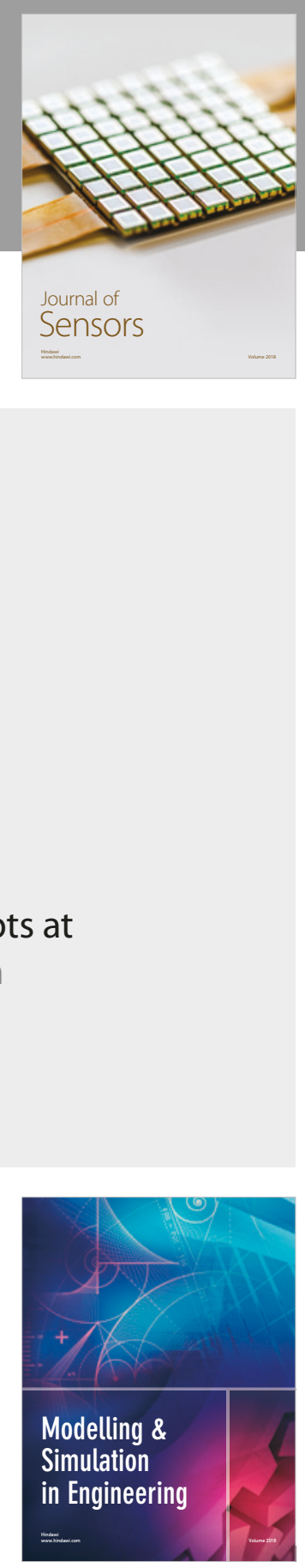

\section{Advances \\ Multimedia}
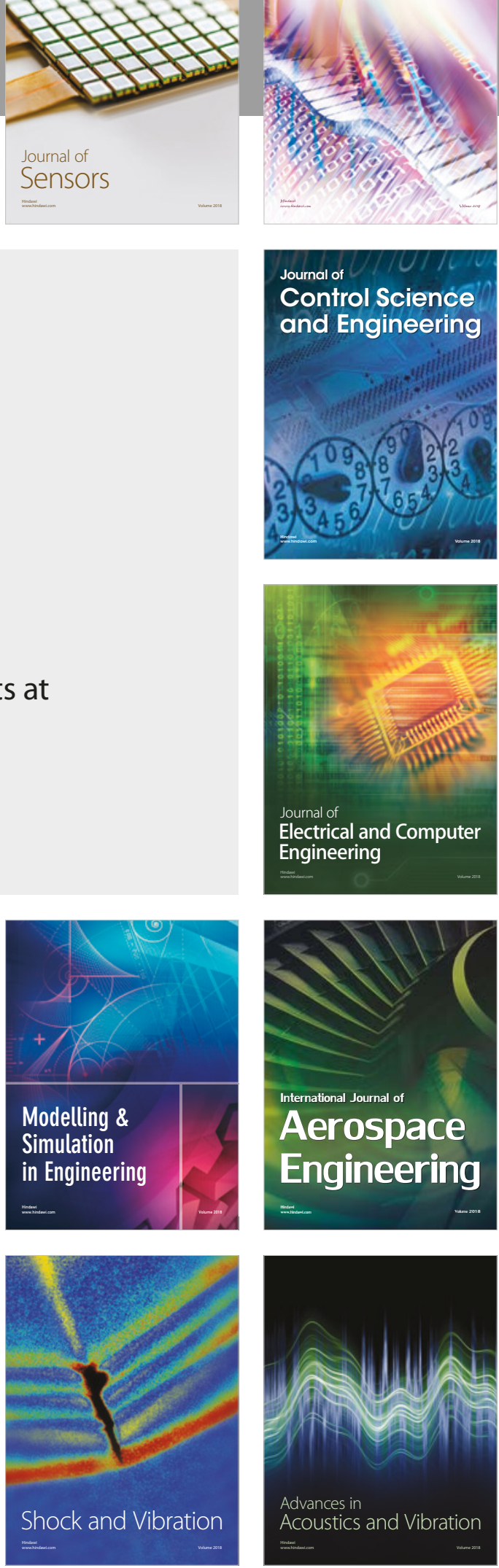